\title{
Viðhorf íslenskra grunnskólanema til eineltis og inngripa í eineltismál út frá reynslu peirra af einelti
}

\author{
Vanda Sigurgeirsdóttir og Ársæll Már Arnarsson
}

- Abstract U Um höfundana $>$ About the authors $>$ Heimildir

Einelti er algengt og alvarlegt vandamál í skólastarfi. •ó að skólayfirvöld hér á landi hafi gripið til ýmissa aðgerða til að sporna við einelti hefur árangurinn ekki verið eins góður og vonast var til. Í pessari rannsókn var skoðuð reynsla íslenskra grunnskólanema af einelti og jafnframt könnuð viðhorf peirra til ýmissa pátta, eins og inngripa kennara, ábyrgðar nemenda, viðbragða áhorfenda og eineltisáætlana skóla. Rannsóknarspurningar voru eftirfarandi: Eru viðhorf nemenda til eineltis ólík eftir reynslu peirra af einelti? Eru viðhorf nemenda til eineltisáætlana og viðbragða við einelti ólík eftir reynslu peirra af einelti? Svarendur voru 10.651 nemandi í 6., 8. og 10. bekk á Íslandi veturinn 2013-14 eða 84\% af heildarfjölda nemenda í pessum árgöngum. Niðurstöður sýna að hægt er að skipta pátttakendum í fjóra hópa eftir tengslum peirra við einelti. Hóparnir eru polendur, gerendur, hvoru tveggja polendur og gerendur og svo bau börn sem ekki tengjast einelti með beinum hætti. Í rannsókninni voru svör pátttakenda við níu spurningum um einelti skoðuð út frá pessum fjórum hópum. Í ljós kom að viðhorf nemendanna lituðust af reynslu peirra af einelti. Gerendur og polendur/gerendur höfðu til að mynda neikvæðari viðhorf til ýmissa pátta. Einnig kom í ljós að aðeins um helmingur pátttakenda taldi sig pekkja eineltisáæetlun skóla síns. Pá vakti athygli að um tíu prósent nemenda töldu að einelti væri polendum að kenna. Auk pess óttaðist nokkur hluti nemenda að mæta í skólann vegna eineltis. Niðurstöður rannsóknarinnar benda til pess að vinna purfi með viðhorf nemenda og auka umræður og fræðslu um eineltisáætlanir og inngrip í eineltismál.

Efnisord: Einelti, polendur, gerendur, áhorfendur, börn.

\section{Inngangur}

Tilgangurinn með pessari rannsókn var að nota niðurstöður íslensks hluta HBSC- (e. Health Behaviors in School-Aged Children) rannsóknarinnar frá árinu 2014 til að skoða viðhorf nemenda til eineltis og inngripa í eineltismál og hvort pessi viðhorf litast af reynslu nemenda af einelti. Deirri reynslu má skipta í fjóra hópa; bein reynsla sem polendur, gerendur og polendur/gerendur og óbein reynsla peirra sem standa utan við eineltið en eru eigi að síður hluti af hópnum, oft kallaðir áhorfendur. Rannsóknir sýna að einelti getur haft neikvæðar afleiðingar fyrir alla pessa hópa. Ekki parf að koma á óvart að afleiðingarnar eru verstar fyrir hópana prjá sem tengjast einelti með beinum hætti, en síðastnefndi hópurinn getur einnig orðið fyrir neikvæðum áhrifum. Má par helst nefna að bekkjarandi og samskipti innan hópa geta skaðast (Reijntjes, Kamphuis, Prinzie og Telch, 2010; Rigby, Smith og Pepler, 2004; Stassen-Berger, 2007; Ttofi og Farrington, 2011). Vegna neikvæðra áhrifa eineltis er mikilvægt að fyrirbyggja pað og stöðva. Sú leið sem helst 
hefur verið notuð er eineltisáætlanir (Ttofi og Farrington 2011). Рó að flestir ef ekki allir skólar á Íslandi séu með eineltisáætlun hefur tíðni eineltis aukist meðal nemenda í 6., 8. og 10. bekk á árunum 2006, 2010, 2014 og 2018 (Ársæll M. Arnarsson og Póroddur Bjarnason, 2012; Vanda Sigurgeirsdóttir, 2017, 2018). Mikilvægt er að skoða hvað veldur og hvaða aðgerðir geta stutt pær eineltisáætlanir sem fyrir eru. Í fræðigreinum um einelti er vinna með skólabrag og menningu oft nefnd sem ein slík aðgerð (Cornell og Bradshaw, 2015). Ef breyta á menningu parf m.a. að vinna með viðhorf og félagslegar hindranir (e. social constraints) sem geta ráðið pví hvort börn grípa inn í eineltismál eða ekki (Paluck, Shepherd og Aronow, 2016). Dví voru í pessari rannsókn settar fram níu fullyrðingar um einelti og inngrip, með pað að markmiði að koma auga á atriði sem betur mega fara, pá sérstaklega hvort beina purfi athygli að viðhorfum eins hóps frekar en annarra. Sambærileg rannsókn hefur ekki verið gerð hér á landi svo vitað sé.

\section{Einelti, skilgreiningar, einkenni og birtingarmyndir}

Einelti hefur alltaf fylgt skólastarfi (Carrera, DePalma og Lameiras, 2011) en var ekki rannsakað með skipulegum og vísindalegum hætti fyrr en á áttunda áratug síðustu aldar (Rigby o.fl., 2004). Í fyrstu var aðeins um örfáar rannsóknir að ræða en smám saman hefur áhuginn aukist. Prátt fyrir pennan aukna áhuga á viðfangefninu er ekki til nein ein skilgreining á einelti. Flestir fræðimenn eru pó sammála um að petta sé endurtekin neikvæð, særandi og niðrandi hegðun sem hefur slæmar afleiðingar fyrir pá sem fyrir verða. Auk pess er minnst á völd og valdaójafnvægi í mörgum skilgreiningum (Browne, 2012; Nansel o.fl., 2001). Pessi skilgreiningarvandi hefur haft ýmis vandkvæði í för með sér. Til að mynda sýna rannsóknir á tíðni mjög mismunandi niðurstöður, allt eftir pví hvernig er spurt og hvaða skilgreining liggur til grundvallar. Getur pví reynst erfitt að bera pær saman (Ársæll M. Arnarsson og Dóroddur Bjarnason, 2009) og í raun óábyrgt að gera slíkt án pess að skoða með ítarlegum hætti bæði skilgreiningar og orðalag spurninga. Í pessari grein er gengið út frá peirri skilgreiningu sem notuð er í spurningalista HBSC-rannsóknarinnar og birtist pátttakendum í spurningalistanum ádur en peir svara spurningum um einelti:

Sagt er að nemandi sé lagður í einelti pegar annar nemandi eða hópur nemenda gera honum eitthvað ópægilegt eða andstyggilegt. Рað er líka einelti pegar nemanda er stöðugt strítt á pann hátt sem honum líkar ekki eða pegar hann er viljandi skilinn útundan. Dað er ekki einelti ef tveir jafn sterkir nemendur rífast eða slást. Pað er heldur ekki einelti pegar nemanda er strítt á vinalegan eða gamansaman hátt (Inchley o.fl., 2016).

Einelti meðal grunnskólabarna fer oftast fram á skólatíma og eru skólalóðin og gangar algengustu staðirnir (Bullock, 2002; Guðjón Ólafsson, 1996; Sharp og Smith, 2000). Eineltið sjálft getur birst á marga vegu en hægt er að skipta birtingarmyndunum í beint og óbeint einelti (Smith, 2004). Líkamlegt einelti, eins og spörk, högg og hrindingar, telst vera beint einelti. Degar um yrt einelti er að ræða, sem einnig flokkast sem beint einelti, eru særandi og niðurlægjandi orð viðhöfð um polandann. Félagslegt einelti er aftur á móti óbeint einelti og felur í sér útilokun, höfnun og baktal (Smokowski og Kopasz, 2005). Rafrænt einelti telst einnig vera óbeint einelti. Dannig getur einelti birst á marga vegu og mikilvægt er að hafa í huga að mest er pað undir yfirborðinu par sem fullorðnir sjá ekki til.

\section{Tíoni eineltis}

Eins og fram hefur komið getur verið erfitt og flókið að bera saman tíðni eineltis milli rannsókna og landa, ekki síst vegna mismunandi orðanotkunar og skilgreininga (Ársæll M. Arnarsson og Póroddur Bjarnason, 2009; Griffin og Gross, 2004). Drátt fyrir pessa erfiðleika er nokkuð ljóst að flest börn upplifa einhvern tíma einelti sem beinir pátttakendur eða sem áhorfendur (James, 2010; Ttofi og Farrington, 2011). Dar af sýna rannsóknir að 20 til 30\% barna tengjast einelti með beinum hætti sem polendur eða gerendur (Gini og Pozzolli, 2009). Pá eru áhorfendur viðstaddir í meirihluta eineltistilfella (Craig og Pepler, 1992; Hawkins, Pepler og Craig, 2001). Dví er ólíklegt að börn fari í gegnum grunnskóla án pess að upplifa eða verða vör við einelti. 
Tíðni eineltis á Íslandi hefur verið rannsökuð nokkuð. Fyrsta umfangsmikla rannsóknin var gerð af Rannsóknastofnun uppeldis- og menntamála skólaárið 1998 til 1999 og tóku 2.000 nemendur 1́ 5., 7. og 9. bekk pátt í henni. Í ljós kom að 13,4\% nemenda í 5. bekk sögðust hafa verið lögð í einelti stundum eða oftar á síðastliðnum vetri, en 6,9\% nemenda í 7. bekk og um 3,3\% nemenda í 9. bekk (Ragnar F. Ólafsson, Ragnar P. Ólafsson og Júlíus K. Björnsson, 1999). Í kjölfar pessarar rannsóknar var svokölluð Olweusaráætlun gegn einelti innleidd í fjölda skóla. Aðrar aðgerðaáæetlanir fylgdu í kjölfarið og nú er svo komið að flestir ef ekki allir grunnskólar á Íslandi eru með einhverja eineltisáætlun. Engu að síður er enn talsvert um einelti i íslenskum skólum. Til merkis um pað sýndu niðurstöður áðurnefndrar rannsóknar, Heilsa og lífskjör skólabarna, annars vegar að polendum hefði fjölgað á árunum 2006 til 2010 (Ársæll M. Arnarsson og Dóroddur Bjarnason, 2012) og hins vegar að tíðni eineltis hefði aukist. Pátttakendurí HBSC-rannsóknunum eru nemendur í 6., 8. og 10. bekk í grunnskólum á Íslandi og hafði peim sem svöruðu pví játandi að hafa verið lagðir í einelti tvisvar til prisvar í mánuði eða oftar fjölgað úr 4,3\% árið 2006 1́ 5,2\% árið 2010, 5,5\% árið 2014 og loks 6,3\% árið 2018 (Vanda Sigurgeirsdóttir, 2016, 2018). Ljóst má pví vera að prátt fyrir fagleg vinnubrögð víða er vandamálið erfitt viðureignar. Đó parf að hafa í huga að aukin umfjöllun á undanförnum árum gæti valdið pví að börn átti sig betur en áđur á pví hvað einelti er.

\section{Hóparnir fjórir: Dolendur, gerendur, polendur/gerendur og áhorfendur}

Degar spurt er um einelti í spurningakönnunum er hægt að skipta pátttakendum í fjóra hópa eftir pví hvernig peir tengjast eineltinu. Dolendur eru peir sem lagðir eru í einelti, gerendur eru peir sem leggja í einelti, polendur/gerendur eru peir sem eru bæði lagðir og leggja í einelti og loks eru pað peir sem ekki tengjast einelti með beinum hætti sem polendur eða gerendur. Hluti pessa síðasttalda hóps er engu að síður áhorfendur. Dessir hópar hafa oft ákveðin sameiginleg einkenni sem tengjast uppeldi og persónuleika en peir eru pó langt í frá einsleitir (Mitsopoulou og Giovazolias, 2015). Allir hóparnir eiga pað sammerkt að einelti hefur neikvæðar afleiðingar fyrir pá, pó að pær séu vissulega misalvarlegar.

\section{Dolendur}

Öll börn geta orðið fyrir einelti en pó má greina ákveðna áhættupætti sem gera pað að verkum að gerendur velja frekar sum börn en önnur til að leggja í einelti. Fjölmennasti hópur polenda er hlédræg börn. Dau eru feimnari, óöruggari, kvíðnari og viðkvæmari en önnur börn. Dessi börn glíma gjarnan við erfiðleika í félagslegum samskiptum, skortir ákveðni og upplifa höfnun og einmanaleika (Cranham og Carrol, 2003; Nansel o.fl., 2001; Smokowski og Kopasz, 2005). Í mörgum tilfellum bregðast pau við áreitni með pví að fara að gráta, vera leið og draga sig í hlé frá öðrum börnum. Vegna pessara viðbragða liggja pau vel við höggi og líklegt er að gerendur haldi áfram særandi og meiðandi hegðun gagnvart peim (Salmivalli, 2010; Vanda Sigurgeirsdóttir, 2003). Ögrandi polendur eru að mörgu leyti andstæða peirra hlédrægu. Dau börn eru oft og tíðum klaufaleg í félagslegum samskiptum og átta sig ekki á peim merkjum sem önnur börn gefa frá sér. Einnig eiga pau pað til að ögra með hegðun sinni, eins og að skemma fyrir í leik og hætta ekki pegar pau eru beðin um pað. Driðji hópur polenda er börn sem tilheyra minnihluta- og jaðarsettum hópum (Knox og Conti-Ramsden, 2003; Mishna, 2003). Mikilvægt er að taka fram að polendur bera ekki ábyrgð á eineltinu sem peir verða fyrir, pótt peir séu feimnir, klaufalegir félagslega, með námserfiðleika eða frá útlöndum, svo eitthvað sé nefnt. Ábyrgðin er gerendanna. Баð breytir pví pó ekki að gerendur eru oft og tíðum að leita að ákveðnum eiginleikum og varnarleysi sem auðveldar peim að ná sínu fram.

Rannsóknir hafa sýnt fram á víðtækar, neikvæðar og langvarandi afleiðingar eineltis fyrir pá sem fyrir pví verða. Dar á meðal á andlega og líkamlega heilsu, svo sem með auknu punglyndi, kvíða og depurð. Đá getur pað haft neikvæð áhrif á sjálfmynd, sjálfsmat og sjálfstraust, ásamt pví að hafa neikvæð áhrif á lífsgleði og vellíðan almennt (Gini og Pozzolli, 2009; Hugh-Jones og Smith, 1999; Klomek, Marrocco, Kleinman, Schonfeld og Gould, 2007; Nansel o.fl., 2001; 
Stassen-Berger, 2007; Ttofi og Farrington, 2011). Рað kemur bví ekki á óvart að skýr tengsl eru á milli eineltis og sjálfsvígshugsana og -tilrauna (Kim, Leventhal, Koh og Boyce, 2009; Klomeck o.fl., 2007). Einnig getur einelti haft neikvæð áhrif á skólagöngu og námsárangur (Ballard, Argus og Remley, 1999; Gini og Pozzolli, 2009). Rannsóknir sýna að afleiðingar eineltis geta fylgt polendum fram eftir ævi (Due o.fl., 2005; Nansel o.fl., 2001; Vanderbilt og Augustyn, 2010) og dregið úr sjálfstrausti og spillt andlegri heilsu og samböndum á fullorðinsárum (Hugh-Jones og Smith, 1999).

\section{Gerendur}

Gerendur eru peir sem meiða og særa önnur börn endurtekið, oft viljandi og með раð аð markmiði að bæta eigin stöðu. Greina má ýmis persónueinkenni og hegðunarmynstur sem margir gerendur eiga sameiginleg en eigi að síður er mikilvægt að benda á að petta er fjölbreyttur hópur. Samkvæmt rannsóknum eru gerendur oft árásarhneigðari en önnur börn, eru með jákvæð viðhorf til ofbeldis, sýna frekar mótpróa og peim gengur verr í námi (Carney og Merrell, 2001; Pepler, Jiang, Craig og Connolly, 2008; Smith, 2004). Dá glíma peir oft við öfund og ótta við að missa völd og stöðu (Piotrowski og Hoot, 2008). Einnig eru sumir gerendur í vandræðum með félagsfærni og sjálfsstjórn, glíma við punglyndi, eru óöruggir og eiga í erfiðleikum með að eignast vini. Ekki glíma pó allir gerendur við pessi vandamál, heldur eru með góða félagsfærni, eiga auðvelt með að stjórna og stýra öðrum, eru félagslega sterkir, í góðum vinasamböndum og jafnvel leiðtogar í hópnum (Ársæll M. Arnarsson og Póroddur Bjarnason, 2009; Campbell, Spieker, Burchinal og Poe, 2006). Deir síðarnefndu nota einelti til að ná enn meiri völdum og betri stöðu í jafningjahópnum (Garandeau og Cillessen, 2006; Pellegrini, 2002).

Að leggja í einelti getur haft ýmsar neikvæðar afleiðingar fyrir pá sem pað gera. Má nefna auknar líkur á kvíða og ýmsum heilsufarstengdum kvillum (Vanda Sigurgeirsdóttir, 2016), hegðunarvanda og árekstrum í skóla (Gini og Pozzolli, 2009), kynferðislegri áreitni (Pellegrini, 2002), áfengis- og vímuefnaneyslu og afbrotum (Nansel o.fl., 2001; Olweus, 2011). Dá gefa rannsóknir vísbendingu um að ef gerendur fá ekki aðstoð og breyta hegðun sinni aukist líkur á að pessi hegðun fylgi peim inn í fullorðinsárin (Smokowski og Kopasz, 2005; Ttofi, Farrington og Lösel, 2012). Sem dæmi sýndi rannsókn Olweus frá 2011 að gerendur voru fjórum sinnum líklegri til að fá sakfellingu fyrir glæp en peir sem voru ekki gerendur. Ef draga á úr tíðni eineltis parf að fækka gerendum, bæði með forvörnum og inngripum. Ef viðhorf gerenda til ýmissa pátta sem snúa að einelti eru pekkt geta aðgerðir orðið árangursríkari.

\section{Dolendur/gerendur}

Priðji hópurinn sem tengist eineltismálum beint og ekki er rætt mikið um hér á landi er börn sem eru bæði polendur og gerendur. Pessi börn eru líklegri til að hafa slaka félagsfærni og brjóta hegðunarreglur hópsins (Greene, 2000; Griffin og Gross, 2004). Sum eru með lítið sjálfstraust, litla sjálfsvirðingu og eiga erfitt með að leysa úr ágreiningi (Andreou, 2001; Carney og Merrell, 2001). Pá eiga pau pað til að kalla fram neikvæð viðbrögð frá öðrum börnum, pirra pau jafnvel, og peim er gjarnan hafnað félagslega af jafningjahópnum (Andreou, 2001). Samkvæmt rannsóknum eru petta pau börn sem verða fyrir mestum skaða af völdum eineltis pví pau upplifa bæði afleiðingar pess að vera polendur og gerendur (Ársæll M. Arnarsson og Póroddur Bjarnason, 2009; Nansel o.fl., 2001). Til að mynda kom í ljós í áðurnefndri HBSC-rannsókn að pau börn sem sögðust vera polendur/gerendur glímdu við víðtækar neikvæðar afleiðingar og voru áhrifin í flestum tilfellum verri en hjá peim börnum sem voru annaðhvort polendur eða gerendur (Vanda Sigurgeirsdóttir, 2016). Er petta í samræmi við niðurstöður erlendra rannsókna (Nansel o.fl., 2001). Dví er líklegt að í pessum hópi séu mörg peirra barna sem purfi hvað mest á aðstoð að halda. 


\section{Áhorfendur}

Sá hópur barna sem ekki tengist einelti með beinum hætti en verður vitni að pví er oft kallaður áhorfendur (e. bystanders). Staða áhorfenda getur verið með prennu móti; peir grípa inn í einelti, hvetja gerendur eða fylgjast hlutlausir með (Cowie, 2000). Áhorfendur eru peir sem helst geta komið í veg fyrir og stöðvað einelti en einnig viðheldur pessi hópur oft einelti (Salmivalli, 2010). Ástæðan fyrir pessu mikla valdi er sú að í yfir 80\% eineltistilvika er einhver að horfa á (Craig og Pepler, 1992; Hawkins o.fl., 2001; O'Connell, Pepler og Craig, 1999). Gerendur vilja nefnilega gjarnan hafa áhorfendur svo að peir geti upphafið sig sjálfa á kostnað polenda og aukið pannig völd sín og vinsældir. Hvetjandi og óvirkir áhorfendur eru draumur gerenda en martröð polenda, pví slík hegðun eykur á vanlíðan peirra og hjálparleysi (Salmivalli, 2010). Rannsóknir sýna að pó að börn í dag viti hvað einelti er og pekki neikvæð áhrif pess kjósa áhorfendur í flestum tilfellum að grípa ekki inn í, oft vegna ótta við gerendur eða við pað að félagsleg staða bíði hnekki (Salmivalli, 2010; Vanda Sigurgeirsdóttir og Hrefna Sigurjónsdóttir, 2017). Petta er að vissu leyti skiljanlegt pví pað að grípa inn í og segja frá er í mörgum hópum brot á félagslegum reglum. Aftur á móti liggur fyrir að ef áhorfendur grípa inn í er hægt að stöðva einelti (Salmivalli, Voeten og Poskiparta, 2011). Hér er pví tækifæri fyrir kennara og fagfólk til að virkja áhorfendur, en án aðstoðar er ólíklegt að hegðun áhorfenda breytist. Vegna pessa beinast tvær fullyrðinganna í rannsókninni að hegðun og viðhorfum áhorfenda til inngripa í eineltismál.

Einelti getur haft neikvæð áhrif á áhorfendur, jafnvel pó að peir tengist pví ekki með beinum hætti (Vanda Sigurgeirsdóttir, 2003; Vanderbilt og Augustyn, 2010). Dó að áhrifin séu eðlilega mun meiri á polendur og gerendur getur pað að verða vitni að einelti einnig haft ýmis neikvæð áhrif. Áhorfendur geta til að mynda orðið hræddir um að verða sjálfir lagðir í einelti og margir finna fyrir óöryggi og jafnvel kvíða. Dá getur pessi ótti og sú menning sem skapast pegar einelti er í gangi haft neikvæð áhrif á nám og námsárangur (Dupper, 2003; Nishina og Juvonen, 2005; Smokowski og Kopasz, 2005). Loks geta gerendur verið fyrirmynd fyrir önnur börn (Juvonen og Ho, 2008).

Miðað við pessar upplýsingar virðist vera augljóst að forvarnir og inngrip í eineltismálum purfi að beinast að öllum hópnum en ekki einstaka börnum (O'Connell o.fl., 1999; Pepler, Smith og Rigby, 2004; Salmivalli, 1998, 1999, 2010). Í peirri rannsókn sem hér er kynnt verður einmitt skoðað hvort munur er á viðhorfum pessara fjögurra hópa nemenda, p.e. polenda, gerenda, polenda/gerenda og áhorfenda. Pekking á pví hvernig viðhorf hópanna fjögurra litast af stöðu peirra og reynslu getur gefið vísbendingar um hvert kennarar og fagfólk skuli beina aðgerðum sínum.

\section{Aðgerðaáætlanir}

Í pessum kafla verður fjallað um aðgerðaáætlanir gegn einelti. Ein fullyrðingin sem pátttakendur 1 rannsókninni tóku afstöðu til beinist að pekkingu nemenda á eineltisáætlunum skólanna sem peir tilheyra. Telja verður mikilvægt að nemendur pekki pessar áætlanir pví pær eru algengasta kerfisbundna aðferðin til að vinna gegn einelti í grunnskólum. Fjölmargar slíkar áætlanir hafa verið settar fram og skila margar peirra árangri samkvæmt rannsóknum (Ttofi og Farrington, 2011). •ó hafa niðurstöður einnig sýnt lítinn eða engan árangur (Ragnar F. Ólafsson, 2008), sérstaklega meðal eldri nemenda (Yeager, Fong, Lee og Espelage, 2015). Hér á landi er skýrt kveðið á um pað í lögum að grunnskólar skuli vera með eineltisáætlun, sbr. eftirfarandi í 30. grein grunnskólalaga frá árinu 2008:

Grunnskólar skulu hafa heildstæða stefnu um pað hvernig fyrirbyggja eigi að líkamlegt, andlegt eða félagslegt ofbeldi eigi sér stað í skólastarfi. Skólar skulu einnig hafa áætlun um framkvæmd tilkynningarskyldu samkvæmt barnaverndarlögum, um hvernig brugðist er við tilvikum um einelti, annað ofbeldi og félagslega einangrun (lög um grunnskóla nr. 91/2008). 
Árið 2011 var síðan sampykkt reglugerð um ábyrgð og skyldur aðila skólasamfélagsins í grunnskólum (nr. 1040/2011) og par kemur fram að grunnskólar skuli setja sér aðgerðaáætlun gegn einelti með virkri viðbragðsáætlun til að takast á við eineltismál í skólanum. Í reglugerðinni kemur einnig fram að kennarar beri ábyrgð á að framfylgja aðgerðaáætlun skólans og skólastjórinn á að samræma aðgerðir. Í Aðalnámskrá grunnskóla (Mennta- og menningarmálaráđuneytið, 2011), almenna hlutanum, segir að mikilvægt sé að grunnskólar komi sér upp forvarnaráætlun sem birt sé í skólanámskrá. Slíkri áætlun er svo nánar lýst:

Í forvarnaráætlun skal m.a.vera áætlun skólans í fiknivörnum og áfengis- og tóbaksvörnum, áætlun gegn einelti og öđru ofbeldi, áætlun í öryggismálum og slysavörnum og stefna í agastjórnun. Einnig skal koma fram með hvaða hætti skólasamfélagið hyggst bregðast við ef mál koma upp. Kynna skal forvarnaráætlun skólans öllum aðilum skólasamfélagsins, starfsfólki skóla, foreldrum og nemendum og birta í skólanámskrá (bls. 43).

Hér kemur skýrt fram að kynna á forvarnaráætlun, par á meðal eineltisáætlun, fyrir nemendum enda hlýtur að vera mikilvægt að nemendur pekki pessa áætlun og viti hvernig hún virkar.

Aðgerðaáætlanir eru mikilvægar og hér á landi hefur verið unnið eftir peim síðan árið 2002. Hins vegar má spyrja sig hvers vegna meiri árangur hafi ekki náðst. Er petta mikilvæg spurning sem skólasamfélagið stendur frammi fyrir, pví einelti tengist vellíðan, velferð og heilsu nemenda með afgerandi hætti. Einn hluti svarsins gæti tengst kennurum og fagfólki, eins og fjallað er um í kaflanum hér á eftir. Svo eru pað nemendurnir sjálfir, en samkvæmt rannsókn Cunningham o.fl. (2016) á viðhorfum 38 drengja og 59 stúlkna á mið- og unglingastigi í grunnskólum í Kanada kom í ljós að peim fannst kynningar á eineltisáætlunum oft leiðinlegar, og töldu að fyrir framan stóran hóp af nemendum virkaði slíkt einfaldlega ekki. Dessi kanadíska rannsókn sýnir hversu mikilvægt pað er að heyra raddir nemendanna sjálfra og kanna viðhorf peirra.

\section{Kennarar og einelti}

Fyrsta fullyrðingin sem pátttakendur rannsóknarinnar tóku afstöðu til fjallar um viðbrögð kennara 1 eineltismálum. Dar sem stór hluti eineltis fer fram á skólatíma bera kennarar, skólastjórnendur og annað fagfólk sem starfar við grunnskóla eðlilega mikla ábyrgð (Garandeau, Vartio, Poskiparta og Salmivalli, 2016; Vanda Sigurgeirsdóttir og Sif Einarsdóttir, 2004; Yoon, Sulkowski og Bauman, 2016). Rannsóknir hafa sýnt að kennurum gengur ekki alltaf vel að taka á einelti pó að peir reyni oftast að grípa inn í fái peir vitneskju um slíkt (Burger, Strohmeier, Spröber, Bauman og Rigby, 2015) og hafi jafnvel fulla trú á pví sjálfir að aðgerðir peirra séu árangursríkar (Boulton og Boulton, 2012). Nemendur eru alla jafna ekki sammála pessu og telja aðgerðir kennara bera mun minni árangur en kennararnir telja sjálfir. Auk pess telja nemendur að ekki sé nægjanlega mikið gert, að kennarar komi ekki auga á nema hluta pess sem er í gangi og að peir vanmeti algengið (Atlas og Pepler, 2001; Bradshaw og Sawyer, 2007; Crothers og Kolbert, 2004; Doll, Song og Siemers, 2004; Vanda Sigurgeirsdóttir, 2003; Varjas, Henrich og Meyers, 2009). Um leið sýna rannsóknir að skortur á inngripi eykur líkur á að einelti haldi áfram (Yoon og Kerber, 2003). Í raun sýna erlendar rannsóknir að kennurum takist aðeins að stöðva einelti í um helmingi tilfella og að í sumum tilfellum geri inngrip peirra vandamálið verra (Davis og Nixon, 2011; Fekkes, Pijpers og Verloove-Vanhorick, 2005). Pannig kom fram í rannsókn Bradshaw og Sawyer (2007) аð 61,5\% nemenda töldu að einelti myndi versna við inngrip kennara.

Degar kennarar og annað fagfólk grípur inn í eineltismál eru prjár útkomur mögulegar: Ástandið versnar, stendur í stað eða batnar (Fekkes o.fl., 2005; Kochenderfer-Ladd og Skinner, 2002; Rigby og Bagshaw, 2003; Smith og Shu, 2000; Vanda Sigurgeirsdóttir, 2017). Dví er ekki öruggt í augum barnanna að einelti muni hætta pó að fullorðnum sé sagt frá. Mikilvægt er að breyta pessu, bæta inngrip og auka pannig tiltrú nemenda á inngripi hinna fullorðnu. Ekki síst er petta mikilvægt vegna pess að einelti fer yfirleitt fram án pess að fullorðnir sjái til og peir eru pví háđir nemendum, sem yfirleitt vita af pessu löngu ádur en hinir fullorðnu komast að pví. Mögulega 
væri hægt að auka markvissa fræðslu og pjálfun í kennaranámi. Árangur af slíku fékkst staðfestur í rannsókn Sairanen og Pfeffer (2011). Auk pess sýna rannsóknir að meirihluti kennara telur að pörf sé á aukinni pjálfun og fræðslu um hvernig eigi að grípa inn í eineltismál (Bradshaw, Waasdorp, O’Brennan og Gulemetova, 2011; Vanda Sigurgeirsdóttir, 2003). Dví verður pað að teljast miður að niðurstöður rannsókna sem gerðar hafa verið hér á landi benda til pess að fræðslan í kennaranámi sé eða hafi ekki verið nægjanleg (Ragnar F. Ólafsson og Ólöf Helga Pór, 2000; Sjöfn Kristjánsdóttir, 2011; Sjöfn Kristjánsdóttir og Vanda Sigurgeirsdóttir, 2011; Vanda Sigurgeirsdóttir, 2003, 2005; Vanda Sigurgeirsdóttir og Sif Einarsdóttir, 2004). Pó skal tekið fram að breytingar hafa orðið á kennaranámi á síðustu árum og pyrfti að gera nýja rannsókn til að skoða stöðuna í dag.

\section{Samantekt og markmið}

Alvarlegar afleiðingar eineltis kalla á árangursríkar leiðir til að fyrirbyggja og grípa inn í eineltismál. Í peirri vinnu eru rannsóknir mikilvægar, en pví miður eru Íslendingar eftirbátar margra annarra pjóða er kemur að rannsóknum og birtingu fræðilegs efnis á pessu sviði. Mikilvægt er bví að fjölga rannsóknum á einelti og birta niðurstöður peirra. Dessi grein á að vera liður í að bæta úr peim skorti. Í greininni er, eins og fram hefur komið, sagt frá niðurstöðum úr eineltishluta rannsóknarinnar Heilsa og lífskjör skólabarna. Viðhorf pátttakenda til níu atriða sem tengjast einelti voru skoðuð. Atriðin sneru að inngripi kennara, ábyrgð nemenda, viðbrögðum áhorfenda, eineltisáætlunum skóla og pví hvort nemendur pyrðu ekki í skólann af ótta við einelti. Mat á pessum páttum getur veitt skólastjórnendum og kennurum mikilvæga innsýn í upplifun nemenda af einelti og viðbrögð við pví. Sérstaklega verður litið til pess hvernig reynsla nemenda af einelti litar viðhorf peirra. Rannsóknarspurningarnar eru tvær. Annars vegar er spurt hvort viðhorf nemenda til eineltis séu ólík eftir reynslu nemenda af einelti Hins vegar er spurt hvort viðhorf nemenda til eineltisáætlana og viðbragða við einelti séu ólík eftir reynslu nemenda af einelti. Tilgáta okkar er sú að polendur, gerendur, polendur/gerendur og áhorfendur hafi ólíkar skoðanir á atriðunum níu.

\section{Aðferð}

\section{Dátttakendur}

Heilsa og lífskjör skólabarna (HBSC) er fjölpjóðleg rannsókn par sem 11, 13 og 15 ára börn eru spurð um ýmsa pætti sem snerta heilsu, líðan og félagslegar aðstæður. Fyrsta fyrirlögnin fór fram veturinn 1983-84 og tóku pá fimm lönd pátt. Rannsóknin hefur síðan verið gerð fjórða hvert ár og nú eru 44 lönd í Evrópu og Norður-Ameríku með í verkefninu. Ísland hefur tekið pátt frá árinu 2006.

\section{Framkvæmd}

Skólaárið 2013-2014 voru 12.678 nemendur í 6., 8. og 10. bekk á Íslandi og fengust svör frá 10.651 sem pýðir að svarhlutfall var 84,0\%. Hér var pví um pýðisrannsókn að ræða með peim fyrirvara að nemendur í sérskólum voru undanskildir. Áður en gagnasöfnun hófst var spurningalistinn ásamt lýsingu á aðferðum sendur til Persónuverndar til sampykktar. Að henni fenginni voru öllum skólastjórum á Íslandi sem voru með nemendur í einhverri af pessum premur bekkjardeildum sendar sömu upplýsingar ásamt ósk um að peir tækju pátt. Aðeins einn skóli hafnaði pátttöku. Síðan var öllum foreldrum og forráðamönnum sent kynningarbréf og peim gefið tækifæri til að hafna pátttöku barnsins. Eitt foreldri kaus að nýta sér pann rétt.

Gagnasöfnun fór fram á tímabilinu frá nóvembermánuði 2013 fram í febrúar 2014. Stöðluð aðferð við söfnun gagna í skólum var notuð par sem spurningalista var dreift í ómerktu umslagi 
meðal nemenda sem mættir voru í kennslustund fyrirlagnardaginn. Borð nemenda voru færð í sundur til pess að tryggja að peir sæju ekki hver hjá öðrum og hver og einn skilaði svo ómerktum spurningalista í umslagið og pað var límt aftur. Á forsíðu listans var stutt lýsing á rannsókninni ásamt skýrum skilaboðum pess efnis að jafnvel pó að foreldrar peirra og skólayfirvöld hefðu gefið leyfi væri nemendum sjálfum algjörlega frjálst að neita pátttöku eða að sleppa pví að svara ákveðnum spurningum. Pegar nemendur höfðu lokið við að svara var listunum safnað saman og peir settir í lokaðan kassa. Nemendum var pví ljóst að um nafnlausa könnun væri að ræða sem ekki yrði rakin til peirra.

Í pessari grein verður fjallað um niðurstöður spurninga sem vörðuðu einelti. Á undan peim kom stutt skilgreining til pess að hjálpa svarendum að skilja betur við hvað væri átt. Hún var sem hér segir: „Hér er spurt um einelti. Sagt er að nemandi sé lagður í einelti pegar annar nemandi eða hópur nemenda gera honum eitthvað ópægilegt eða andstyggilegt. Рað er líka einelti pegar nemanda er stöðugt strítt á bann hátt sem honum líkar ekki eða begar hann er viljandi skilinn útundan. Рað er ekki einelti ef tveir jafn sterkir nemendur rífast eða slást. Dað er heldur ekki einelti pegar nemanda er strítt á vinalegan eða gamansaman hátt.“

\section{Mælitæki og tölfræðileg úrvinnsla}

Tvær spurningar fjölluðu um pað hversu oft nemendurnir hefðu haft reynslu af einelti undanfarna mánuði og voru peir annars vegar spurðir hversu oft peir hefðu verið lagðir í einelti og hins vegar hversu oft peir hefðu tekið pátt í að leggja annan nemanda í einelti. Báðum spurningum var hægt að svara með sömu fimm möguleikunum (frá „Aldrei“ til „Nokkrum sinnum í viku“) en við úrvinnslu gagna var ekki horft til tíðni heldur einungis pess hvort nemendur hefðu einhvern tíma eða aldrei haft reynslu af einelti á tímabilinu. Út frá pessum svörum var nemendum skipt í fjóra flokka: 1) Deir sem höfðu verið lagðir í einelti, 2) Deir sem höfðu lagt aðra í einelti, 3) Deir sem bæði höfðu lagt aðra í einelti og verið sjálfir lagðir í einelti og 4) Deir sem höfðu ekki haft beina reynslu af einelti á undanförnum mánuðum. Hafa ber í huga að í síðastnefnda hópnum er, samkvæmt rannsóknum, talsverður fjöldi áhorfenda (Craig og Pepler, 1992; Hawkins o.fl., 2001; O’Connell o.fl., 1999). Í rannsókninni voru börnin ekki sérstaklega spurð hvort pau hefðu orðið vitni að einelti.

Nemendur voru einnig beðnir að taka afstöðu til eftirfarandi fullyrðinga um einelti og gefa til kynna hversu sammála eða ósammála peir væru: 1) Umsjónakennarinn minn bregst alltaf við pegar pað kemur upp einelti í bekknum, 2) Ef nemendur sem verða vitni af einelti skipta sér af pá hættir eineltið, 3) Deir nemendur sem leggja í einelti eru vinsælir, 4) Ég pekki eineltisáætlun skólans míns og veit hvernig hún virkar, 5) Einelti er polendunum sjálfum um að kenna, 6) Skólinn ætti að hafa samband við foreldra allra í bekknum pegar einelti kemur upp, 7) Degar ég verð vitni af neikvæðri stríðni og einelti pá bregst ég alltaf við og reyni að hjálpa, 8) Ég vil ekki hafa neitt einelti í bekknum mínum, 9) Ég pori stundum ekki í skólann af ótta við neikvæða stríðni og einelti. Svarmöguleikarnir við öllum fullyrðingunum voru „Mjög sammála“, „Frekar sammála“, „Hvorki sammála né ósammála“, „Frekar ósammála“ og „Mjög ósammála“. Dessar fullyrðingar voru búnar til af öðrum höfundi pessarar greinar (VS) og var bætt inn í HBSCspurningalistann.

Við tölfræðiútreikninga var kí-kvaðrat notað til að rannsaka tengsl milli flokka nafnbreyta. Mikilvægt er að hafa í huga að í gagnasafni af pessari stærð kemur oft fram tölfræðilega marktækur munur, jafnvel pótt munur milli hópa sé lítill.

\section{Niðurstöður}

Af 10.566 nemendum sem svöruðu spurningum um einelti sögðust 13,2\% (1.391) einhvern tíma hafa verið lögð í einelti á undanförnum mánuðum, 5,4\% (569) höfðu lagt aðra í einelti og 4,4\% 
(466) höfðu reynslu af hvoru tveggja. Mikill meirihluti nemenda, eða 77,0\% (8.140), kvaðst enga reynslu hafa haft af slíku á pví tímabili sem um var spurt. Sá hópur verður í pessum kafla kallaður hvorugt-hópurinn.

\section{Viðbrögð við einelti}

Mynd 1 sýnir hversu líklegt nemendur töldu að umsjónarkennarinn peirra brygðist við ef einelti kæmi upp í bekknum. Í öllum fjórum hópunum voru flestir mjög eða frekar sammála pví að kennarinn myndi bregðast við en engu að síður er ljóst að peir tveir hópar sem ekki höfðu orðið fyrir einelti voru mun líklegri til að vera jákvæðir en hinir. Deir nemendur sem höfðu annaðhvort eingöngu verið lagðir í einelti eða lögðu einnig aðra í einelti voru á hinn bóginn líklegri til að vera frekar eða mjög ósammála - 16\% í fyrrnefnda hópnum og 20\% í peim síðarnefnda. Kíkvaðrat sýndi að marktækur munur var á svörum pátttakenda eftir pví hver reynsla peirra af einelti $\operatorname{var}(\mathrm{X} 2(12, \mathrm{~N}=10566)=218,76, \mathrm{p}<0,001)$.

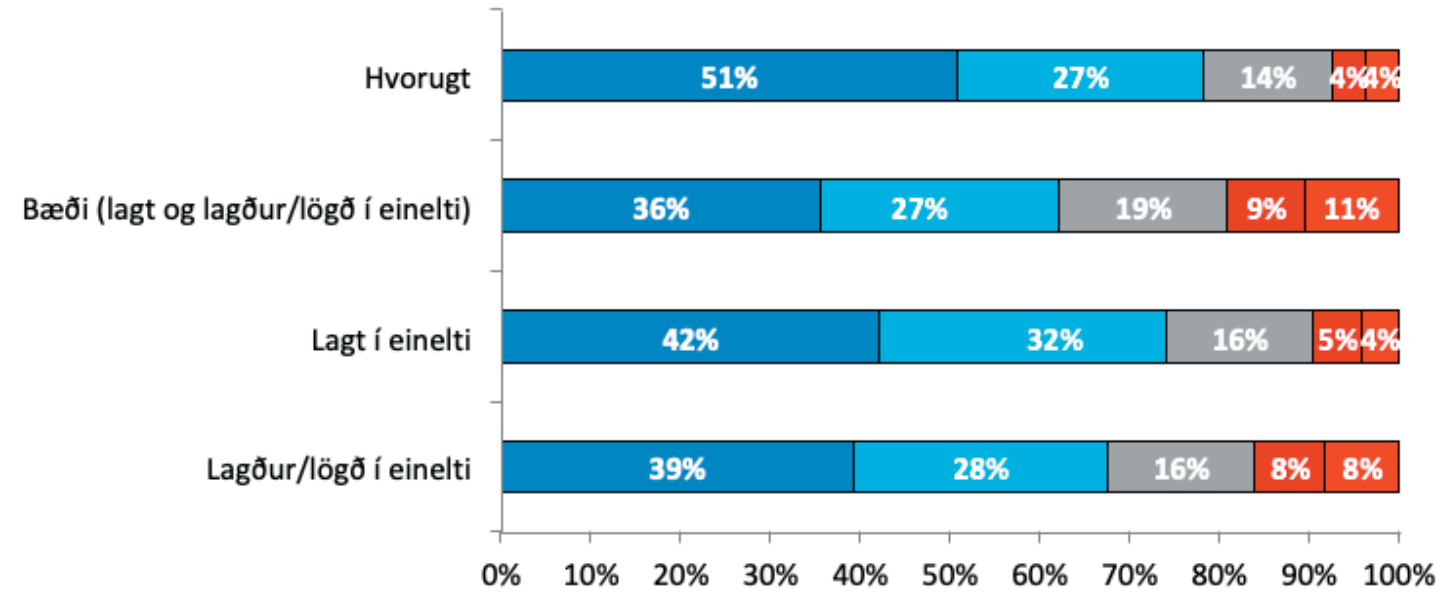

$\square$ Mjög sammála $\square$ Frekar sammála $\square$ Hvorki sammála né ósammála $\square$ Frekar ósammála $\square$ Mjög ósammála

Mynd 1. „Umsjónarkennarinn minn bregst alltaf við pegar pað kemur upp einelti í bekknum.“

Mynd 2 sýnir hversu stórt hlutfall nemenda taldi sig pekkja eineltisáætlun skóla síns. Fram komu veik en marktæk tengsl svara eftir pví hver reynsla nemenda af einelti var (X2 (12, $\mathrm{N}=10413)$ $=52,64, \mathrm{p}<0,001)$, en ef rýnt er í myndina sést vel að hóparnir gefa að mestu leyti ápekk svör. Mesta athygli vekur hins vegar hversu margir nemendur virðast ekki pekkja áætlun skóla síns. Aðeins um helmingur nemenda sagðist mjög eða frekar sammála fullyrðingu pess efnis. 


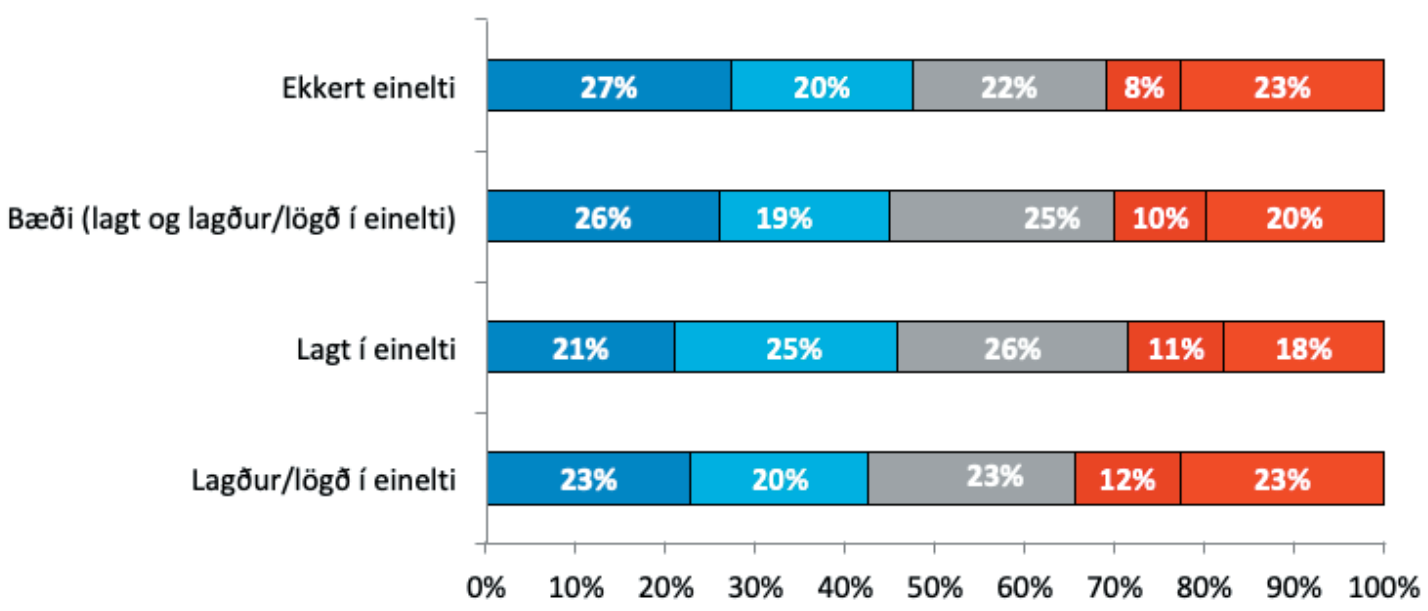

$\square$ Mjög sammála $\square$ Frekar sammála $\square$ Hvorki sammála né ósammála $\square$ Frekar ósammála $\square$ Mjög ósammála

Mynd 2. „Ég pekki eineltisáætlun skólans míns og veit hvernig hún virkar.“

Eins og fram kemur á mynd 3 voru peir sem leggja ađra í einelti fyrirsjáanlega ólíklegri til pess аð vilja að haft væri samband við alla foreldra í bekknum ef einelti kæmi upp. Бó að munurinn milli hópanna reyndist vera marktækur pá var hann ekki ýkja stór $(X 2(12, N=10527)=82,05$, p <0,001) enda virtust flestir nemendur peirrar skoðunar að petta væri ákjósanleg nálgun.

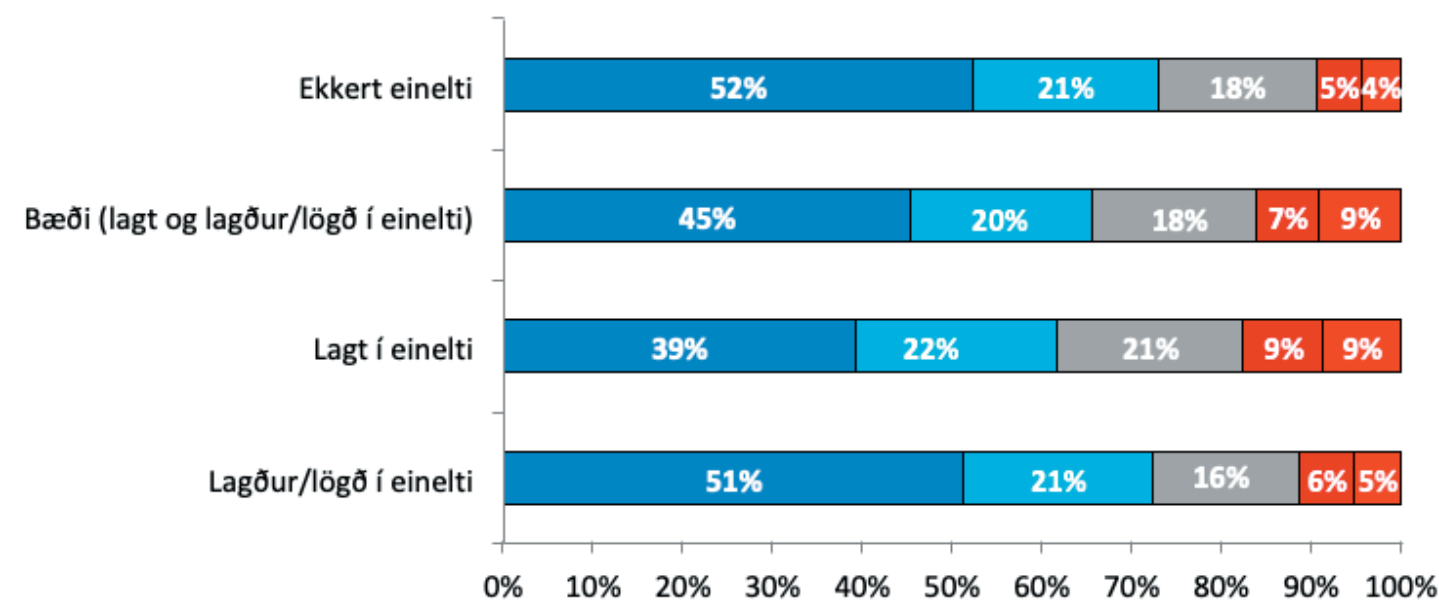

$\square$ Mjög sammála $\square$ Frekar sammála $\square$ Hvorki sammála né ósammála $\square$ Frekar ósammála $\square$ Mjög ósammála

Mynd 3. „Skólinn ætti að hafa samband við foreldra allra í bekknum pegar einelti kemur upp.“

Á mynd 4 sést hversu líklegt nemendur töldu að peir myndu skerast í leikinn ef peir yrðu vitni að neikvæðri stríðni eða einelti. Langflestir nemendur virtust trúa pví að peir myndu ekki láta slíkt viðgangast, en peir sem höfðu lagt aðra í einelti voru samt marktækt ólíklegri til að vera peirrar skoðunar $(\mathrm{X} 2(12, \mathrm{~N}=10502)=333,52, \mathrm{p}<0,001)$. 


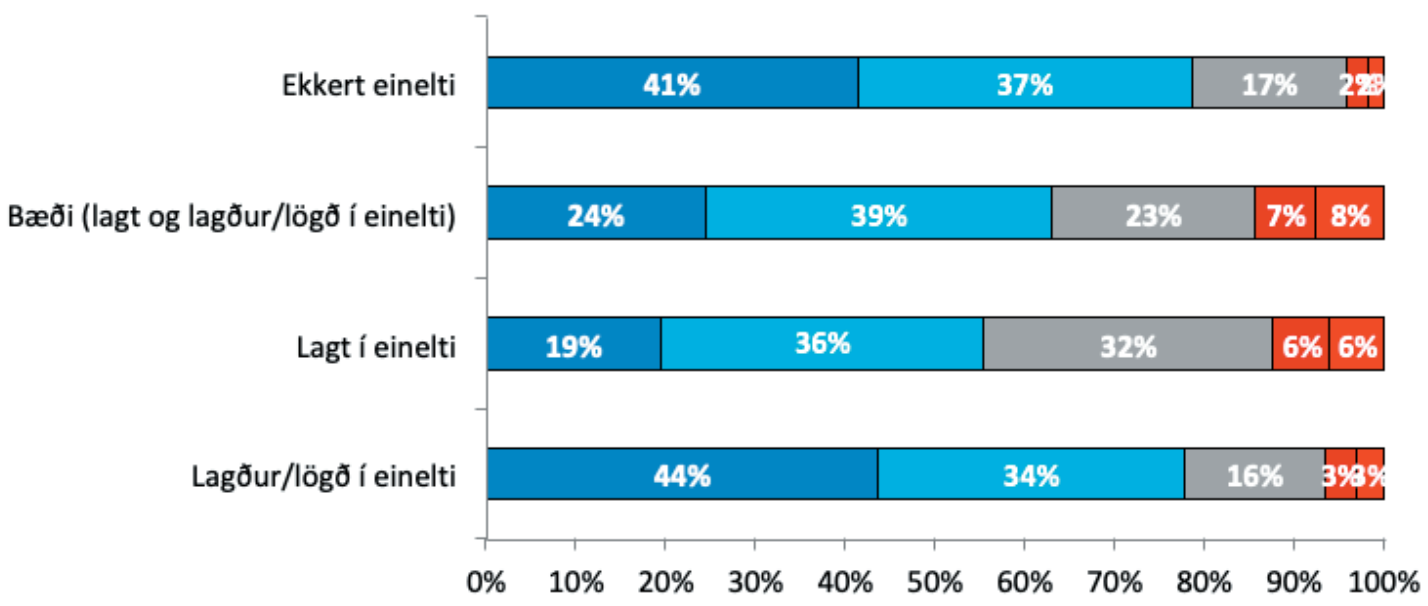

$\square$ Mjög sammála $\square$ Frekar sammála $\square$ Hvorki sammála né ósammála $\square$ Frekar ósammála $\square$ Mjög ósammála

Mynd 4. „Degar ég verð vitni að neikvæðri stríðni og einelti pá bregst ég alltaf við og reyni að hjálpa."

\section{Viðhorf til eineltis}

Mynd 5 sýnir að pó að flestir nemendur hafi verið frekar eða mjög ósammála pví að einelti sé polendum að kenna voru peir sem lögðu í einelti mun líklegri en aðrir til að telja sök liggja hjá polendunum $(\mathrm{X} 2(12, \mathrm{~N}=10427)=282,26, \mathrm{p}<0,001)$.

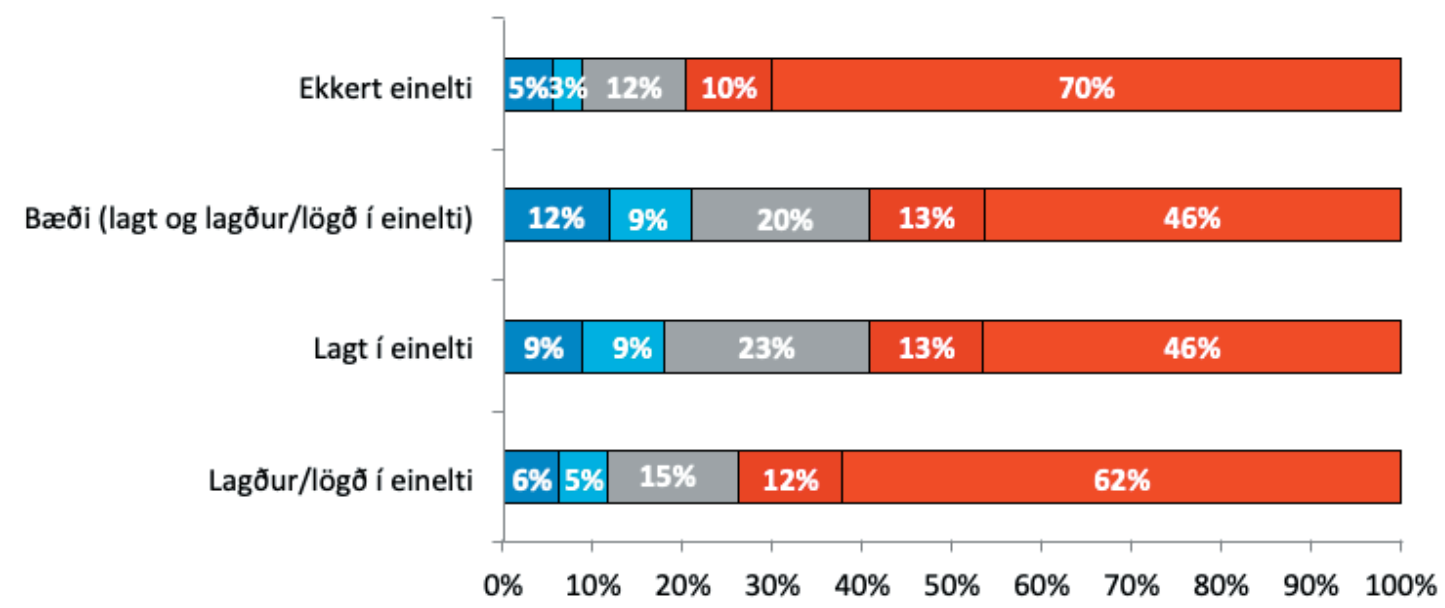

$\square$ Mjög sammála $\square$ Frekar sammála $\square$ Hvorki sammála né ósammála $\square$ Frekar ósammála $\square$ Mjög ósammála

Mynd 5. „Eineltið er polendunum sjálfum að kenna.“

Spurt var um meintar vinsældir gerenda eineltis og eru niðurstöðurnar sýndar á mynd 6 . Nokkur breytileiki var milli svara eftir reynslu pátttakanda af einelti $(X 2(12, \mathrm{~N}=10442)=321,17, \mathrm{p}$ $<0,001)$. Deir nemendur sem enga reynslu höfou af einelti á pessu tímabili voru ólíklegastir til að telja gerendur vinsæla. Hinir prír hóparnir voru hins vegar líklegri til að telja svo vera og sást enginn teljanlegur munur milli peirra nema hvað gerendurnir sjálfir voru ólíklegri en hinir tveir hóparnir til að vera mjög sammála fullyrðingunni. 


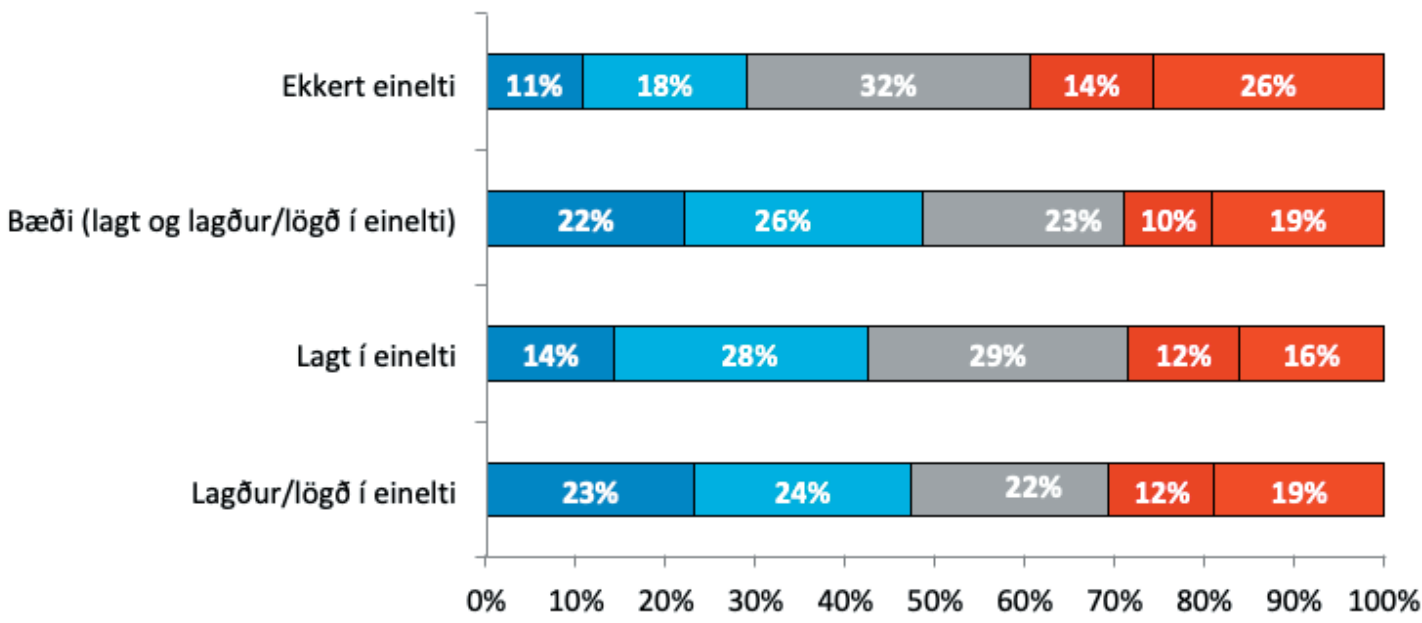

$\square$ Mjög sammála $\square$ Frekar sammála $\square$ Hvorki sammála né ósammála $\square$ Frekar ósammála $\square$ Mjög ósammála

Mynd 6. „Deir nemendur sem leggja í einelti eru vinsælir.“

Á mynd 7 sést hversu líklegt svarendurnir töldu að ef nemendur sem yrðu vitni að einelti skiptu sér af pví myndi pað hætta. Kí-kvaðrat sýndi marktækan mun á svörum pátttakenda eftir pví hver reynsla peirra af einelti var $(X 2(12, N=10449)=299,27, p<0,001)$ og ljóst var að peir nemendur sem höfðu verið lagðir í einelti voru mun svartsýnni á áhrifamátt samnemenda sinna en hinir. Dannig sögðust 25\% peirra sem höfðu verið lagðir í einelti vera mjög eða frekar ósammála pessu. Í sama streng tóku 30\% peirra sem bæði höfðu lagt og verið lagðir í einelti. Athygli vekur að í öllum fjórum hópunum voru frekar fáir sem voru mjög sammála fullyrðingunni (13-19\%).

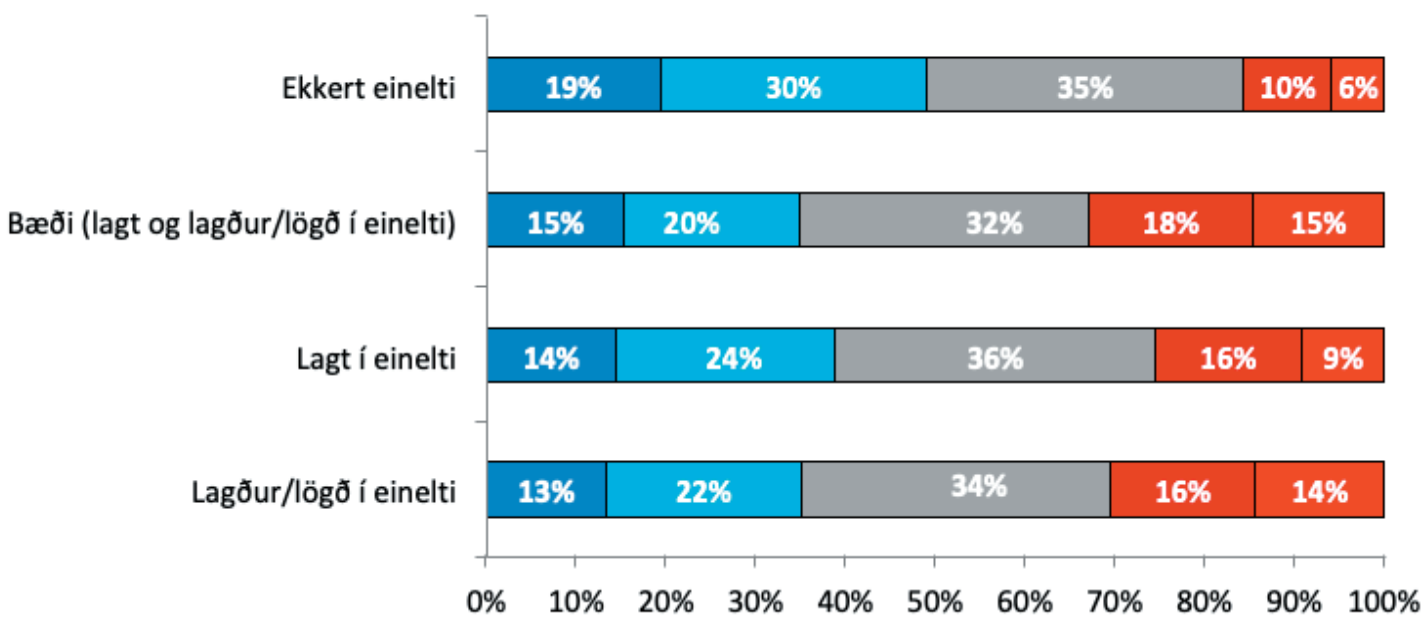

\section{$\square$ Mjög sammála $\square$ Frekar sammála $\square$ Hvorki sammála né ósammála ■Frekar ósammála $\square$ Mjög ósammála}

Mynd 7. „Ef nemendur sem verða vitni að einelti skipta sér af pá hættir eineltið.“

Mynd 8 sýnir hversu stórt hlutfall nemenda vildi ekki hafa einelti í bekknum sínum. Athygli vekur að hvergi voru allir mjög eða frekar sammála pessari fullyrðingu. Deir sem lagt höfðu aðra í einelti voru jafnframt síður líklegir til að vera sammála henni en aðrir (X2 (12, N = 10543) = $353,24, \mathrm{p}<0,001)$. 


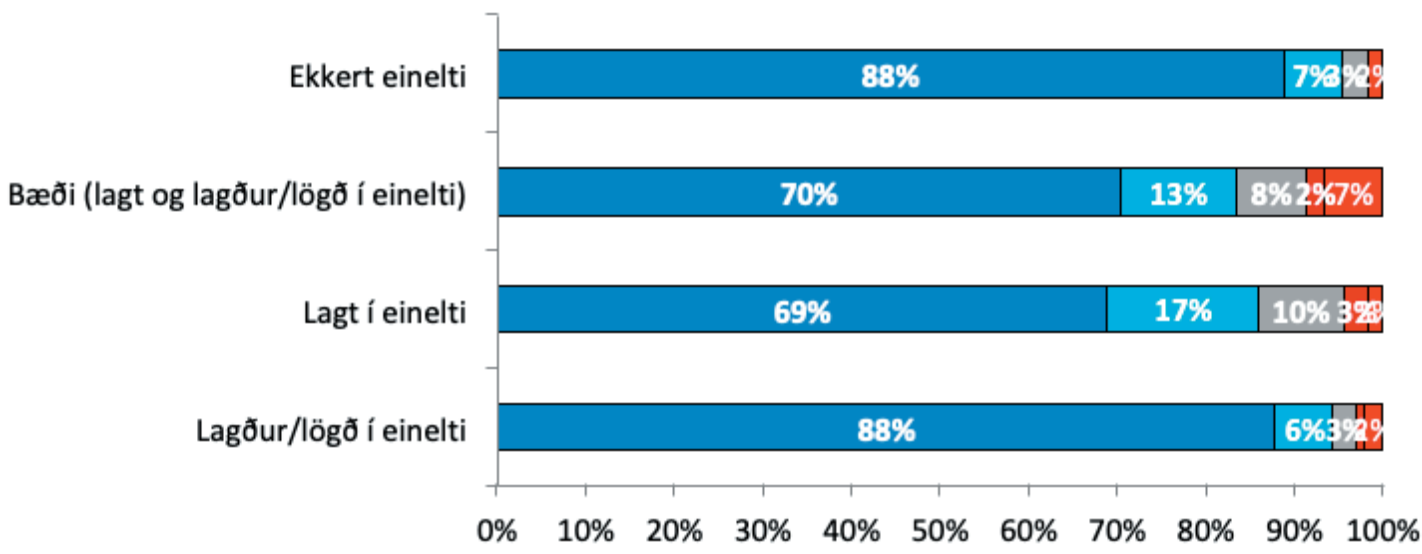

\section{$\square$ Mjög sammála $\square$ Frekar sammála $\square$ Hvorki sammála né ósammála $\square$ Frekar ósammála $\square$ Mjög ósammála}

Mynd 8. „Ég vil ekki hafa neitt einelti í bekknum mínum.“

\section{Ótti við einelti}

Nemendur voru einnig spurðir hvort peir pyrðu stundum ekki í skólann af ótta við neikvæða stríðni eða einelti. Eins og sést á mynd 9 var talsverður munur á afstöðu peirra eftir pví hver reynslan af einelti var undanfarna mánuði. Deir sem höfðu enga slíka reynslu eða höfðu lagt aðra nemendur í einelti voru miklu líklegri til að vera frekar eða mjög ósammála pessari fullyrðingu (82-87\%) en peir sem höfðu reynt pað á eigin skinni (55-56\%). Dannig voru peir sem höfðu verið lagðir í einelti mun líklegri en aðrir til að pora ekki í skólann. Kí-kvaðrat sýndi að pessi munur milli hópanna var marktækur $(\mathrm{X} 2(12, \mathrm{~N}=10516)=1217,56, \mathrm{p}<0,001)$.

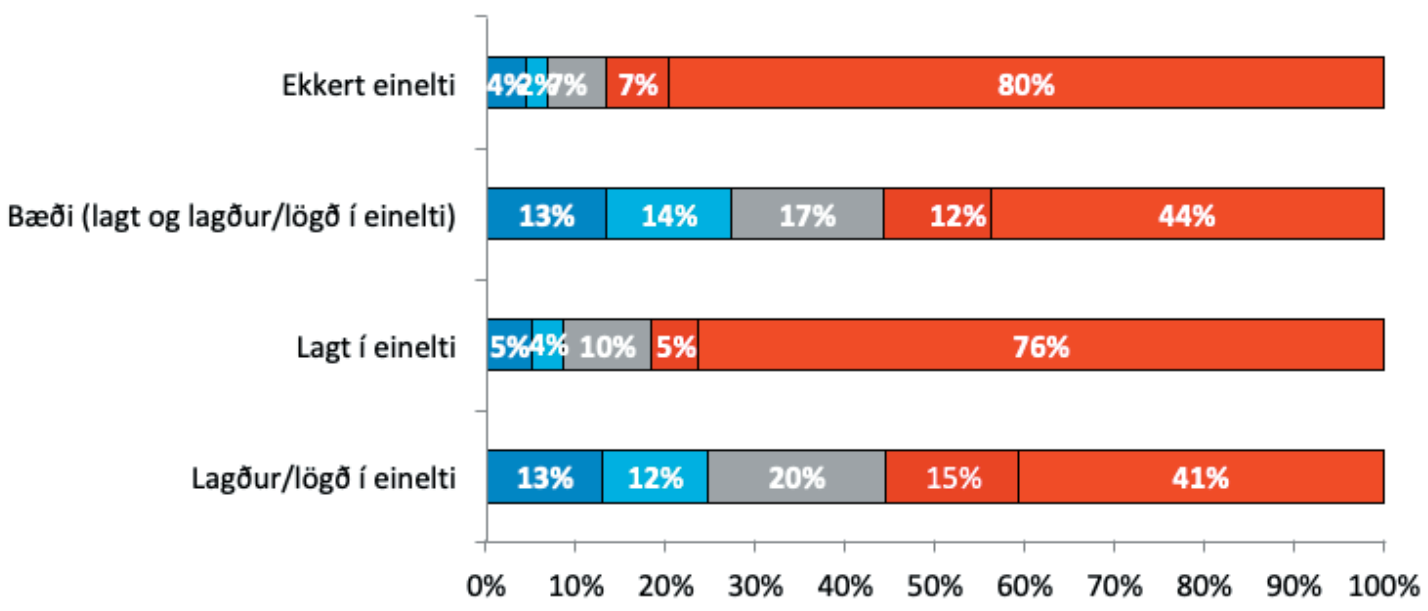

$\square$ Mjög sammála $\square$ Frekar sammála $\square$ Hvorki sammála né ósammála $\square$ Frekar ósammála $\square$ Mjög ósammála

Mynd 9. „Ég pori stundum ekki í skólann af ótta við neikvæða stríðni og einelti.“ 


\section{Umræða}

Einelti er alvarlegt, flókið og hefur, eins og fram hefur komið, neikvæð áhrif á einstaklinga og skólabrag. Verið er að vinna gott starf víða og eru flestir ef ekki allir grunnskólar á Íslandi með eineltisáætlanir. Drátt fyrir pað sögðu 6,3\% nemenda í 6., 8. og 10. bekk árið 2018 að peir hefðu verið lagðir í einelti tvisvar til prisvar í mánuði eða oftar (Vanda Sigurgeirsdóttir, 2018). Ljóst má pví telja að eineltisáætlanir einar og sér duga ekki til. Dví parf að afla nýrrar pekkingar sem nýta má við að bæta forvarnir og gera inngrip árangursríkari. Vonir standa til að pessi rannsókn verði einn pátturinn í peirri vinnu. Tilgangur rannsóknarinnar var að skoða viðhorf nemenda í 6., 8. og 10. bekk í grunnskóla til níu fullyrðinga um einelti. Niðurstöðurnar voru síðan skoðaðar út frá reynslu svarenda af einelti með pað að markmiði að kanna hvort hún hefði áhrif á viðhorf peirra. Helstu niðurstöður eru pær að gerendur og polendur/gerendur greina sig frá hinum tveimur hópunum í mikilvægum páttum pegar kemur að viðhorfum og viðbrögðum við einelti. Í pessum kafla verður fjallað nánar um pessar niðurstöður.

\section{Viðbrögð við einelti}

Í fyrsta lagi var spurt um fjórar fullyrðingar sem tengjast viðbrögum við einelti. Fullyrðingarnar skipta verulegu máli, ekki síst inngrip kennara en pað er grundvallaratriði pegar kemur að pví að lækka tíðni eineltis (Craig og Pepler, 1997; Davis og Nixon, 2011; Fekkes o.fl., 2005; Yoon og Kerber, 2003).

Jákvætt verður pví að teljast að samtals voru um 70\% pátttakenda mjög eða frekar sammála peirri fullyrðingu að umsjónarkennarar peirra brygðust allaf við pegar upp kæmi einelti í bekknum. Greinilegur munur var á svörum pátttakenda eftir pví hvaða hópi, af hópunum fjórum, peir tilheyrðu. Dannig voru 16\% polenda og 20\% polenda/gerenda frekar eða mjög ósammála pessari fullyrðingu en $8 \%$ hvorugt-hópsins og 9\% gerenda. Dessu parf að breyta ef vel á að vera. Líklegt má telja að fræðsla og pjálfun í kennaranámi myndi breyta miklu hér um, pví pannig má auka líkur á árangursríku inngripi, eins og fram kom í rannsókn Sairanen og Pfeffer (2011). Tekið skal fram að ekki var spurt um árangur inngrips, en nauðsynlegt er að gera slíka rannsókn hér á landi pví erlendar rannsóknir sýna ýmis vandkvæði kennara við að taka á einelti, par á meðal að peir nái aðeins árangri í um helmingi tilfella (Bradshaw og Sawyer, 2007; Davis og Nixon, 2011; Fekkes o.fl., 2005).

Eins og fram hefur komið er eineltisáætlun helsta tæki grunnskóla í vinnunni gegn einelti. Athygli vekur hversu margir pátttakendur sögðust ekki pekkja eineltisáætlun skóla síns eða vita hvernig hún virkaði. Aðeins tæplega helmingur pátttakenda var frekar eða mjög sammála peirri fullyrðingu. Ekki var mikill munur eftir hópunum fjórum en pó voru polendur ólíklegastir til að vera pessu sammála, eða 35\%. Svo almennt pekkingarleysi er mikið áhyggjuefni og ættu grunnskólar landsins að bregðast við hið snarasta. Í aðalnámskrá grunnskóla (Mennta- og menningarmálaráðuneytið, 2011) kemur fram að kynna á forvarnaráætlun fyrir nemendum. Velta má fyrir sér hvort pað sé yfirleitt ekki gert eða hvort pað sé pá gert á stórum samkomum pegar athygli margra í nemendahópnum er takmörkuð. Miðað við rannsókn Cunningham o.fl. (2016) væri skynsamlegt að hafa nemendur með í ráðum pegar kemur að ákvörðunum um hvernig best sé að standa að peirri vinnu.

Foreldrar eru afar mikilvægir í allri vinnu gegn einelti. Dví er ánægjulegt að pátttakendur voru almennt á pví að hafa ætti samband við foreldra allra í bekknum kæmi upp einelti. Deir sem helst voru ósammála voru gerendur og polendur/gerendur, sem kemur ekki á óvart. Út frá niðurstöðum fræðimanna um að inngrip eigi að beinast að öllum hópnum en ekki einstaka börnum (Polanin, Espelage og Pigott, 2012; Salmivalli, 2010) hlýtur að purfa að upplýsa foreldra allra barna um stöðu mála. Detta er hægt að gera á fundi, með tölvupósti og símtali. Í gegnum tíðina hefur verið misbrestur á pessu sem vonandi verður bætt úr, ekki síst í ljósi pess að niðurstöður rannsóknarinnar sýna að pað er vilji meirihluta nemenda. 
Dátttakendur sögðust flestir ekki láta einelti viðgangast heldur brygðust alltaf við og reyndu að hjálpa. Pó var greinilegur munur á gerendum og polendum/gerendum sem sögðust gera slíkt í mun minni mæli en hinir tveir hóparnir. Jákvæett er hversu margir nemendur sögðust alltaf bregðast við en pær niðurstöður eru á skjön við erlendar rannsóknir sem sýna að áhorfendur segjast hika við að skipta sér af vegna ótta við að verða sjálfir lagðir í einelti eða missa félagslega stöðu (Padgett og Notar, 2013; Salmivalli o.fl., 2011). Gera pyrfti frekari rannsóknir á vettvangi til að skoða petta nánar.

Í heild er athyglisvert hvað peir sem lögðu í einelti sem gerendur og polendur/gerendur skáru sig úr í mörgum páttum. Sýnir pað svo ekki er um villst hversu mikilvægt pað er að finna pessi börn og reyna að leysa vanda peirra.

\section{Viðhorf til eineltis}

Nemendur voru einnig beðnir að taka afstöðu til fjögurra fullyrðinga um viðhorf til eineltis. Viðhorf geta haft áhrif á menningu og hegðunarreglur í hópum og pá um leið á hegðun, svo sem inngrip í eineltismál (Paluck o.fl., 2016). Til að mynda geta viðhorf sem eru á pá leið að einelti sé polendum sjálfum að kenna valdið pví að einelti sé réttlætt og dregið úr hvatanum til að rétta polanda hjálparhönd. Sýnir petta mikilvægi pess að kanna viðhorf grunnskólanemenda til ýmissa pátta eineltis.

Degar kom að fullyrðingunni um að einelti væri polendunum sjálfum að kenna er athyglisvert að aðeins rúmlega helmingur gerenda og polenda/gerenda, eða 59\%, tóku afstöðu gegn pessari fullyrðingu og 18 og 21\% peirra voru henni frekar eða mjög sammála. Pá voru 8\% hvorugt-hópsins og $11 \%$ polenda einnig sammála pví að einelti væri polendum að kenna. Detta eru alvarlegar niðurstöður, sem benda til pess að fræðsla um einelti sé ekki nægjanleg og skili sér ekki nógu vel. Parna mætti taka mið af niðurstöðum Cunningham o.fl. (2016) sem sýndu að hluti hópsins hlustar ekki pegar kynning og fræðsla fer fram, svo og að sumir gera beinlínis uppreisn á móti peim gildum sem hinir fullorðnu eru að leitast við að innleiða. Að sama skapi hafa rannsóknir sýnt að pað skilar bestum árangri að leggja áherslu á samkennd (e. empathy) og koma um leið skýrum skilaboðum til gerenda um að hegðun peirra verði ekki liðin (Cunningham o.fl., 2016; Garandeau o.fl., 2016). Nauðsynlegt er að breyta peim viðhorfum að einelti sé polendum að kenna pví pau réttlæta verknaðinn og gera inngrip erfiðara. Đá geta viðbrögð af pví tagi ýtt undir skömm og valdið vanlíðan og komið í veg fyrir að polendur láti vita af einelti.

Tæpur helmingur gerenda, polenda/gerenda og polenda var frekar eða mjög sammála pví að peir sem leggja í einelti séu vinsælir og í sama streng tók um priðjungur hópsins sem hafði engin bein tengsl við einelti. Pessar niðurstöður gætu opnað leið til að nálgast gerendur og breyta hegðun peirra með pví að leggja sérstaka áherslu á pað hvernig farsælast sé að afla sér vinsælda og viðhalda peim - m.ö.o. að verða jákvæður frekar en neikvæður leiðtogi í félagahópnum.

Svipaða sögu var að segja af viðhorfum pátttakenda til pess hvort einelti stöðvaðist ef áhorfendur yrðu vitni að pví og skiptu sér af. Deir sem tengdust einelti beint höfðu minni trú á pessu. Athygli vakti að einungis 13 til 19\% allra pátttakenda voru mjög sammála pessari fullyrðingu. Ĺḱlegt má telja að pessi viðhorf valdi pví að nemendur grípi síður inn í. Mikilvægt er að finna leiðir til að auka tiltrú nemenda á möguleikum peirra til að stöðva eineltistilvik pví rannsóknir par sem fylgst er með á vettvangi sýna að skipti nemendur sér af stöðvast einelti í um helmingi tilfella (Craig, Pepler og Atlas, 2000; O’Connell o.fl., 1999).

Meirihluti pátttakenda vildi ekkert einelti í sínum bekk en gerendur og polendur/gerendur í minni mæli en hinir. Afar athyglisvert er að alls ekki allir nemendur tóku skýra afstöðu gegn einelti í svörum sínum. Dannig voru 2\% hópsins sem hafði ekki upplifað einelti og 3\% polenda mjög eða frekar ósammála fullyrðingunni. Hugsanlega skýrist petta af andspyrnu nokkurra nemenda gegn allri eineltisvinnu, eins og kom fram í rannsókn Cunningham o.fl. (2016). 
Í heild benda niðurstöður til pess að viðhorf meirihluta grunnskólanema til eineltis séu eins og best verður á kosið en nokkur hluti hópsins sé með viðhorf sem unnið geti gegn árangursríkri vinnu gegn einelti. Eru gerendur og polendur/gerendur í ákveðinni sérstöðu hvað petta varðar.

\section{Ótti við einelti}

Síðasta fullyrðingin sneri að ótta við að fara í skólann. Um fjórðungur polenda og polenda/ gerenda sagðist frekar eða mjög sammála pegar peir voru spurðir hvort peir pyrðu stundum ekki í skólann af ótta við einelti. Detta er í senn bæði skiljanleg og afar neikvæð niðurstaða. Einnig verður að teljast athyglisvert аð $6 \%$ peirra barna sem tengjast ekki einelti með beinum hætti voru frekar eða mjög sammála sömu fullyrðingu. Í heild voru um 1.000 börn af peim 10.566 sem tóku pátt frekar eða mjög sammála peirri fullyrðingu að pau pyrðu stundum ekki í skólann af ótta við einelti. Mikilvægt er að skólasamfélagið taki pessar niðurstöður alvarlega og grípi til aðgerða. Ótti við að fara í skólann getur framkallað sállíkamleg einkenni eins og höfuðverk og magaverk að morgni skóladags, ásamt pví að geta haft neikvæð áhrif á skólasókn og námsárangur (Akiba, 2008). Er pessi ótti í samræmi við erlendar rannsóknir (Addington og Yablon, 2011). Til að mynda sýndi rannsókn meðal nemenda í 8. bekk í 33 löndum að 28,5\% pátttakenda óttuðust að verða fyrir ofbeldi í skólanum (Akiba, 2008). Đá sýndu rannsóknir frá Bandaríkjunum að 7\% nemenda í 8. bekk voru heima í pað minnsta einn dag í mánuði af ótta við einelti (Glew, Rivara og Feudtner, 2000). Önnur rannsókn benti til pess að fimmtungur nemenda á miðstigi forðaðist salernin í skólanum af ótta við einelti (Foltz-Gray, 1996) og sú priðja að sama hlutfall upplifði hræðslu stóran hluta skóladagsins (Hazier, Hoover og Oliver, 1992).

\section{Lokaorð}

Niðurstöður rannsóknarinnar sýna með beinum hætti að vinna parf með viðhorf nemenda, pá sérstaklega gerenda og polenda/gerenda, til eineltis og inngripa í eineltismál. Pá parf að fara í vandlega skoðun á pví hvernig fræðsla um einelti og eineltisáætlanir fer fram í grunnskólum. Auk pess parf að taka á ótta barna við að fara í skólann. Niðurstöðurnar benda einnig í átt að nokkrum úrlausnaratriðum sem minnkað gætu einelti í íslenskum grunnskólum. Djálfun og fræðsla í kennaranámi er eitt peirra atriða sem parf að skoða. Dá er mikilvægt að líta á einelti sem félagslegt vandamál alls hópsins og pví parf að vinna með menningu, viðhorf og hegðunarreglur barnahópsins (Brenick og Halgunseth, 2017; Salmivalli, 2010; Salmivalli o.fl., 2011). Einnig parf að ná betur til foreldra alls barnahópsins. Loks er mikilvægt að hafa börnin sjálf með í ráđum pegar kemur að vinnu gegn einelti. Börn verða vitni að eineltisatvikum sem fullorðnir sjá ekki (Craig o.fl., 2000), pau pekkja menninguna og hegðunarreglur og átta sig á peim félagslega veruleika sem pau lifa og hrærast í. Dví eru pau í góðri aðstöðu til að koma með gagnlegar tillögur um hvernig bæta megi inngrip í eineltismál (Crothers, Kolbert og Barker, 2006; Cunningham, Cunningham, Ratcliffe og Vaillancourt, 2010).

Einelti í grunnskólum er ógn við velferð nemenda. Рað er einnig brot á mannréttindasáttmálum og andstætt gildum skóla og siðareglum fagfólks. Hins vegar er einelti bæði flókið og erfitt viðureignar, sérstaklega ef pað er langt gengið. Dví eru forvarnir og fræðsla mikilvæg til að breyta viðhorfum eins og ýmsum peim sem fram koma í niðurstöðum pessarar rannsóknar. Dær gefa góðar vísbendingar um pætti sem vinna parf með og er óskandi að skólasamfélagið geri pað, til heilla fyrir öll börn.

\section{Attitudes of Icelandic school-children towards bullying and interventions}

Bullying is a serious and prevalent problem in schools in Iceland as in the rest of the world. Despite various actions taken by authorities to counter bullying, the results have not been as hoped for. In the latest wave of the Health behaviour in school-aged 
children in Iceland in 2018, 6.3\% of students in 6th, 8th and 10th grade reported that they had been bullied 2-3 times a month or more often.

In the current study we looked at the experience and attitudes of Icelandic schoolchildren regarding several relevant factors, such as teacher intervention, student responsibilities, audience response, anti-bullying programs at school and fear of bullying. The aim of the study was to examine attitudes of elementary school students toward bullying and its interventions.

Responses were collected from 10,651 students in 6th, 8th, and 10th grade in Iceland during the 2013-14 school year which equals $84 \%$ of the whole population for these age-groups.

The questions on bullying were preceded by the following definition: "Here are some questions about bullying. We say a person is being bullied when another person or a group of people, repeatedly say or do unwanted nasty and unpleasant things to him or her. It is also bullying when a person is teased in a way he or she does not like or when he or she is left out of things on purpose. The person that bullies has more power than the person being bullied and wants to cause harm to him or her. It is not bullying when two people of about the same strength or power argue or fight". The came two questions - one on bullying: "How often have you taken part in bullying another person(s) in school in the past couple of months?"; the other on victimization: "How often have you been bullied in school in the past couple of months?" There were five possible answers to both questions: 1) Never, 2) It has happened once or twice, 3) 2 or 3 times a month, 4) About once a week, and 5) Several times a week. For the purpose of this study only 2 or 3 times a month or more was considered as bullying.

On the basis of responses students were divided into four groups; bullies, victims, bully-victims and those not affected by bullying. Nine questions were analyzed based on this classification.

We found that students' experience of bullying strongly affected their attitudes toward it. Bullies and bully-victims were, for example, more negative towards several factors. Most students were convinced that their teacher would react if there was bullying in the class, but those who had experienced bullying were less optimistic than their peers. We also found that only half of the students were aware of the anti-bullying program in their school. Most thought that the teacher should contact the parents in case of bullying, although the perpetrators were somewhat less enthusiastic about that. Most students felt they would intervene if they witnessed bullying, but bullies were significantly less likely to think so. Interestingly, around $10 \%$ believed that bullying was the victim's fault. A substantial proportion of the participants believed that bullies were popular amongst their peers, and those that were either victims or bullies were more favorable towards this question than those who had no direct experience. Less than half of students believed that bullying would cease if other students intervened, with those having no experience of it themselves being most optimistic. A significant proportion of students expressed fear of attending school due to bullying. Around $95 \%$ of students who were victims or had no experience of bullying claimed that they wished that there was no bullying in their class. For those who had bullied the figure was around $85 \%$.

These results indicate that more needs to be done in terms of students' attitudes, antibullying programs and interventions.

Key words: Bullying, victims, bullies, bystanders, children. 


\section{Um höfundana}

Vanda Sigurgeirsdóttir (vand@hi.is) er lektor í tómstunda- og félagsmálafræði við menntavísindasvið Háskóla Íslands.Vanda hefur um árabil rannsakað einelti á Íslandi, ásamt pví að vinna mikið á vettvangi, með kennurum og öðru fagfólki sem vinnur með börnum.

Ársæll Arnarsson (arsaell@hi.is) er prófessor í tómstunda- og félagsmálafræði við Menntavísindasvið Háskóla Íslands. Hann lauk BA-prófi í sálfræði 1993, MS-gráðu í heilbrigðisvísindum 1997 og PhD-gráđu í líf- og læknavísindum frá H.Í. árið 2009. Síðastliðinn áratug hafa rannsóknir hans aðallega beinst að heilsufari og líðan unglinga.

\section{About the authors}

Vanda Sigurgeirsdóttir (vand@hi.is) is an assistant professor in the Department of Leisure and Social studies at the School of Education, University of Iceland.Vanda has been studying bullying in Iceland for many years. She also does field work with teachers and other professionals who work with children.

Ársæll Arnarsson (arsaell@hi.is) is a professor of leisure studies in the University of Iceland School of Education. He completed a BA degree in psychology in 1993, an MSc degree in Health Sciences in 1997 and a PhD in Biomedical Sciences in 2009 from the University of Iceland. For the past decade his research has focused on the health and well-being of adolescents.

\section{Heimildir}

Addington, L.A. ogYablon,Y. B. (2011). How safe do students feel at school and while traveling to school? A comparative look at Israel and the United States. American Journal of Education, 117(4), 465-493. doi:10.1086/660755

Akiba, M. (2008). Predictors of student fear of school violence: A comparative study of eighth graders in 33 countries. School Effectiveness and School Improvement, 19(1), 51-72. doi:10.1080/09243450801936878

Andreou, E. (2001). Bully/victim problems and their association with coping behavior in conflictual peer interactions among school-age children. Educational Psychology, 21(1), 59-66. doi:10.1080/01443410125042

Atlas, R. S. og Pepler, D. J. (2001). Observations of bullying in the classroom. Journal of Educational Research, 92(2), 86-99. doi:10.1080/00220679809597580

Ársæll M. Arnarsson og Póroddur Bjarnason. (2009). Einelti og samskipti við fjölskyldu og vini meðal 6., 8. og 10. bekkinga. Tímarit um menntarannsóknir, 6, 15-26.

Ársæll M. Arnarsson og Póroddur Bjarnason. (2012). Einelti meðal íslenskra skólabarna 2006-2010. Í Sveinn Eggertsson og Ása G. Ásgeirsdóttir (ritstjórar), Djóðarspegill - Rannsóknir í félags- og mannvísindum XIII (bls. 1-9). Reykjavík: Félagsvísindastofnun Háskóla Íslands.

Ballard, M., Argus, T. og Remley, T. P. (1999). Bullying and school violence: A proposed prevention program. NASSP Bulletin, 83(607), 38-47.

Boulton, M.J. og Boulton, R. (2012). Resistant to the message:Are pupils unreceptive to teachers' anti-bullying initiatives and if so why? Eductional Studies, 38(5), 485-489. doi:10.1080/03055698.2011.643112

Bradshaw, C. P. og Sawyer, A. L. (2007). Bullying and peer victimization at school: Perceptual differences between students and school staff. School Psychology Review, 36(3), 361-383.

Bradshaw, C. P., Waasdorp, T. E., O’Brennan, L. M. og Gulemetova, M. (2011). Findings from the National Education Association's nationwide study of bullying: Teachers' and education support professionals' perspectives. Washington, DC: National Education Association.

Brenick, A. og Halgunseth, L. C. (2017). Brief note: Applying developmental intergroup perspectives to the social ecologies of bullying: Lessons from developmental social psychology. Journal of Adolescence, 59, 90-95. doi:10.1016/j. adolescence.2017.05.018

Browne, N.T. (2012). Weight bias, stigmatization, and bullying of obese youth. Bariatric Nursing and Surgical Patient Care, 7(3), 107-115. doi:10.1089/bar.2012.9972

Bullock,J. R. (2002). Bullying among children. Childhood Education, 78(3),130-133. doi:10.1080/00094056.2002.10522721

Burger, C., Strohmeier, D., Spröber, N., Bauman, S. og Rigby, K. (2015). How teachers respond to school bullying: An examination of self-reported intervention strategy use, moderator effects, and concurrent use of multiple strategies. Teaching and Teacher Education, 51, 191-202. doi:10.1016/j.tate.2015.07.004 
Campbell, S. B., Spieker, S., Burchinal, M. og Poe, M. D. (2006). Trajectories of aggression from toddlerhood to age 9 predict academic and social functioning through age 12. Journal of Child Psychology and Psychiatry, 47(8), 791-800. doi:10.1111/j.1469-7610.2006.01636.x

Carney, A. G. og Merell, K. W. (2001). Perspectives on understanding and preventing an international problem. School Psychology International, 22(3), 364-382. doi: 10.1177/0143034301223011

Carrera, M.V., DePalma, R. og Lameiras, M. (2011). Toward a more comprehensive understanding of bullying in school settings. Educational Psychology Review, 23(4), 479-499. doi:10.1007/s10648-011-9171-x

Cornell, D. og Bradshaw, C. P. (2015). From a culture of bullying to a climate of support: The evolution of bullying prevention and research. School Psychology Review, 44(4), 499-503. doi:10.17105/spr-15-0127.1

Cowie, H. (2000). Bystanding or standing by: Gender issues in coping with bullying in English schools. Aggressive Behavior, 26(1), 85-97. doi:10.1002/(SICI)1098-2337(2000)26:1<85::AID-AB7>3.0.CO;2-5

Craig, W. M. og Pepler, D. J. (1992). Contextual factors in bullying and victimization [grein kynnt á ráđstefnu kanadíska sálfæðingafélagsins í Toronto í Kanada].

Craig, W. M. og Pepler, D. J. (1997). Naturalistic observations of bullying and victimization on the playground [óbirt skýrsla]. Toronto, ON: LaMarsh Research Centre on Violence and Conflict Resolution, York University.

Craig, W. M., Pepler, D. og Atlas, R. (2000). Observations of bullying in the playground and in the classroom. School Psychology International, 21(1), 22-36. doi:10.1177/0143034300211002

Cranham,J. og Carroll,A. (2003). Dynamics within the bully/victim paradigm:A qualitative analysis. Educational Psychology in Practice, 19(2), 113-132. doi:10.1080/02667360303235

Crothers, L. M. og Kolbert, J. B. (2004). Comparing middle school teachers' and students' views on bullying and anti-bullying interventions. Journal of School Violence, 3(1), 17-32. doi:10.1300/ J202v03n01_03

Crothers, L. M., Kolbert, J. B. og Barker,W. F. (2006). Middle school students' preferences for anti-bullying interventions. School Psychology International, 27(4), 475-487. doi:10.1177/0143034306070435

Cunningham, C. E., Cunningham, L. J., Ratcliffe, J. og Vaillancourt, T. (2010). A qualitative analysis of the bullying prevention and intervention recommendations of students in grades 5 to 8. Journal of School Violence, 9(4), 321-338. do i:10.1080/15388220.2010.507146

Cunningham, C. E., Mapp, C., Rimas, H., Cunningham, L., Vaillancourt,T., Mielko, S. og Marcus, M. (2016). What limits the effectiveness of antibullying programs? A thematic analysis of the perspective of students. Psychology of Violence, 6(4), 596-606. doi:10.1080/15388220.2015.1095100

Davis, S. og Nixon, C. (2011). What students say about bullying. Educational Leadership, 69(1), 18-23.

Doll, B., Song, S. og Siemers, E. (2004). Classroom ecologies that support or discourage bullying. Í D. L. Espelage og S. M. Swearer (ritstjórar), Bullying in American schools: A social-ecological perspective on prevention and intervention (bls. 161-183). Mahwah, NY: Erlbaum.

Due, P., Holstein, B. E., Lynch, J., Diderrichsen, F., Gabhain, S. N., Scheidt, P. og Currie, C. (2005). Bullying and symptoms among school-aged children: International comparative cross sectional study in 28 countries. European Journal of Public Health, 15(2), 128-132. doi:10.1093/eurpub/cki105

Dupper, D. R. (2003). School social work, skills \& interventions for effective practice. Hoboken, NJ:John Wiley and Sons.

Fekkes, M., Pijpers, F. I. M. ogVerloove-Vanhorick, S. P. (2005). Bullying: Who does what, when and where? Involvement of children, teachers and parents in bullying behavior. Health Education Research: Theory and Practice, 20(1), 81-91. doi:10.1093/her/cyg100

Foltz-Gray, D. (1996). The bully trap:Young tormentors and their victims find ways out of anger and isolation. Teaching Tolerance, 5(2), 18-23.

Garandeau, C. F. og Cillessen, A. (2006). From indirect aggression to invisible aggression: A conceptual view on bullying and peer group manipulation. Aggression and Violent Behavior, 11(6), 641-654. doi:10.1016/j.avb.2005.08.004

Garandeau, C. F.,Vartio,A., Poskiparta, E. og Salmivalli, C. (2016). School bullies' intention to change behavior following teacher interventions: Effects of empathy arousal, condemning of bullying, and blaming of the perpetrator. Prevention Science, 17(8), 1034-1043. doi:10.1007/s11121-016-0712-x

Gini, G. og Pozzolli, T. (2009). Association between bullying and psychosomatic problems: A meta-analysis. Pediatrics, 123(3), 1059-1065. doi:10.1542/peds.2008-1215

Glew, G., Rivara, F. og Feudtner, C. (2000). Bullying: Children hurting children. Pediatrics in Review, 21(6), 183-189. PMID: 10854313.

Greene, M. B. (2000). Bullying and harassment in schools. Í R. S. Moser og C. E. Franz (ritstjórar), Shocking violence:Youth perpertrators and victims - a multidisciplinary perspective (bls. 72-101). Springfield, IL: Charles C. Thomas.

Griffin, R. S. og Gross, A. M. (2004). Childhood bullying: Current empirical findings and future directions for research. Aggression and Violent Behavior, 9(4), 379-400. doi:10.1016/S1359-1789(03)00033-8 
Guðjón Ólafsson. (1996). Einelti. Reykjavík: Uppi hf., Ritröð uppeldis og menntunar.

Hawkins, D. L., Pepler, D. og Craig, W. M. (2001). Naturalistic observations of peer interventions in bullying. Social Development, 10(4), 512-527. doi:10.1111/1467-9507.00178

Hazier, R., Hoover, J. og Oliver, R. (1992). What children say about bullying. Executive Educator, 14, 20-22.

Hugh-Jones, S. og Smith, P. K. (1999). Self-reports of short- and long-term effects of bullying on children who stammer. British Journal of Educational Psychology, 69(2), 141-158. PMID: 10405616.

Inchley, J., Currie, D., Young, T., Samdal, O., Torsheim, T., Augustson, L. . . og Barnekow, V. (2016). Growing up unequal: gender and socioeconomic differences in young people's health and well-being. Health Behaviour in School-aged Children (HBSC) study: International report from the 2013/2014 survey. Kaupmannahöfn:WHO Regional Office for Europe.

James, A. (2010). School bullying. Research briefing. Sótt af http://www.nspcc.org.uk/inform/research/briefings/school_bullying_pdf_wdf73502.pdf

Juvonen, J. og Ho, A.Y. (2008). Social motives underlying antisocial behavior across middle school grades. Journal of Youth and Adolescence, 37(6), 747-756. doi:10.1007/s10964-008-9272-0

Kim,Y. S., Leventhal, B. L., Koh,Y.-J. og Boyce,W.T. (2009). Bullying increased suicide risk: Prospective study of Korean adolescents. Archives of Suicide Research, 13(1), 15-30. doi:10.1080/13811110802572098

Klomek, A. B., Marrocco, F., Kleinman, M., Schonfeld, I. S. og Gould, M. S. (2007). Bullying, depression, and suicidality in adolescents. Journal of the American Academy of Child and Adolescent Psychiatry, 46(1), 40-49. doi:10.1521/suli.2008.38.2.166

Knox, E. og Conti-Ramsden, G. (2003). Bullying risks of 11-year old children with specific language impairment (SLI): Does school placement matter? International Journal of Language and Communication Disorders, 38(1), 1-12. PMID: 12569033.

Kochenderfer-Ladd, B. og Skinner, K. (2002). Children's coping strategies: Moderators of the effects of peer victimization? Developmental Psychology, 38(2), 267-278. PMID: 11881761.

Lög um grunnskóla nr. 91/2008.

Mennta- og menningarmálaráðuneytið. (2011). Aðalnámskrá grunnskóla: Almennur hluti. Reykjavík: Höfundur.

Mishna, F. (2003). Learning disabilities and bullying: Double jeopardy. Journal of Learning Disabilities, 36(4), 336-347. do i: $10.1177 / 00222194030360040501$

Mitsopoulou, E. og Giovazolias, T. (2015). Personality traits, empathy and bullying behavior: A meta-analytic approach. Aggression and Violent Behavior, 21, 61-72. doi:10.1016/j.avb.2015.01.007

Nansel,T. J., Overpeck, M., Pilla, R. S., Ruan, W. J., Simons-Morton, B. og Scheidt, P. (2001). Bullying behaviors among US youth: Prevalence and association with psychosocial adjustment. Journal of the American Medical Association, 285(16), 2992-3100. PMID: 11311098.

Nishina, A. og Juvonen, J. (2005). Daily reports of witnessing and experiencing peer harassment in middle school. Child Development, 76(2), 435-450. doi:10.1111/j.1467-8624.2005.00855.x

O'Connell, P., Pepler, D. og Craig,W. (1999). Peer involvement in bullying: Issues and challenges for intervention. Journal of Adolescence, 22(2), 437-452. doi:10.1006/jado.1999.0238

Olweus, D. (2011). Bullying at school and later criminality: Findings from three Swedish community samples of males. Criminal Behaviour and Mental Health, 21(2), 151-156. doi:10.1002/cbm.806

Padgett, S. og Notar, C. E. (2013). Bystanders are the key to stopping bullying. Universal Journal of Educational Research, 1(2), 33-41. doi:10.13189/ujer.2013.010201

Paluck, E. L., Shepherd, H. og Aronow, P. M. (2016). Changing climates of conflict: A social network experiment in 56 schools. Proceedings of the National Academy of Sciences, 113(3), 566-571. doi:10.1073/pnas.1514483113

Pellegrini,A.D. (2002). Bullying, victimization, and sexual harassment during the transition to middle school. Educational Psychologist, 37(3), 151-163. doi:10.1207/S15326985EP3703_2

Pepler, D., Jiang, D., Craig,W. og Connolly, J. (2008). Developmental trajectories of bullying and associated factors. Child Development, 79(2), 325-338. doi:10.1111/j.1467-8624.2007.01128.x

Pepler, D., Smith, P. K. og Rigby, K. (2004). Looking back and looking forward: Implications for making interventions work effectively. Í P. K. Smith, D. Pepler og K. Rigby (ritstjórar), Bullying in schools. How successful can interventions be (bls. 307-324). Cambridge: Cambridge University Press.

Piotrowski, D. og Hoot, J. (2008). Bullying and violence in schools. What teachers should know and do. Childhood Education, 84(6), 357-363. doi:10.1080/00094056.2008

Polanin,J. R., Espelage, D. L. og Pigott,T. D. (2012). A meta-analysis of school-based bullying prevention programs' effects on bystander intervention behavior. School Psychology Review, 41(1), 47-65.

Ragnar F. Ólafsson. (2008). Mat á árangri af Olweusaráatlun gegn einelti. Reykjavík: Námsmatsstofnun.

Ragnar F. Ólafsson og Ólöf Helga Dór. (2000). Úrræði skóla við lausn á eineltisvandamálum. Niðurstöður rannsóknar, sem unnin var af Rannsóknastofnun uppeldis- og menntamála fyrir Menntamálaráduneytið í samvinnu við Kennarasamband Íslands. Reykjavík: Rannsóknastofnun uppeldis- og menntamála. 
Ragnar F. Ólafsson, Ragnar P. Ólafsson og Júlíus K. Björnsson. (1999). Umfang og eðli eineltis i íslenskum grunnskólum. Niðurstöður rannsóknar sem unnin var af Rannsóknastofnun uppeldis- og menntamála fyrir Menntamálaráduneytið. Reykjavík: Rannsóknastofnun uppeldis- og menntamála.

Reglugerð um ábyrgð og skyldur aðila skólasamfélagsins í grunnskólum nr. 1040/2011.

Reijntjes, A., Kamphuis, J. H., Prinzie, P. og Telch, M. J. (2010). Peer victimization and internalizing problems in children: A meta-analysis of longitudinal studies. Child Abuse and Neglect, 34(4), 244-252. doi:10.1016/j.chiabu.2009.07.009

Rigby, K. og Bagshaw, D. (2003). Prospects of adolescent students collaborating with teachers in addressing issues of bullying and conflict in schools. Educational Psychology, 23(5), 535-546. doi:10.1080/0144341032000123787

Rigby, K., Smith, P. K. og Pepler, D. (2004). Working to prevent school bullying: Key issues. Í P. K. Smith, D. Pepler og K. Rigby (ritstjórar), Bullying in schools. How successful can interventions be (bls. 1-12). Cambridge: Cambridge University Press.

Sairanen, L. og Pfeffer, K. (2011). Self-reported handling of bullying among junior high school teachers in Finland. School Psychology International, 32(2). Sótt af http://spi.sagepub.com/content/32/3/330

Salmivalli, C. (1998). Not only bullies and victims: Participation in harassment in school classes - some social and personality factors (óútgefin doktorsritgerð). Háskólinn í Turku, Finnlandi.

Salmivalli, C. (1999). Participant role approach to school bullying: Implications for interventions. Journal of Adolescence, 22(4), 453-459. doi:10.1006/jado.1999.0239

Salmivalli, C. (2010). Bullying and the peer group:A review. Aggression and Violent Behavior, 15(2), 112-120. doi:10.1016/j. avb.2009.08.007

Salmivalli, C., Voeten, M. og Poskiparta, E. (2011). Bystanders matter: Associations between reinforcing, defending, and the frequency of bullying behavior in classrooms. Journal of Clinical Child and Adolescent Psychology, 40(5), 668-676. doi:10.1080/15374416.2011.597090

Sharp, S. og Smith, P. K. (ritstjórar). (2000). Gegn einelti. Handbók fyrir skóla (Ingibjörg Markúsdóttir pýddi). Reykjavík:Æskan.

Sjöfn Kristjánsdóttir. (2011). „Ég varð bara að lava pað af reynslunni“: Mat kennara á freððslu og pjálfun í eineltismálum í kennaranámi (oútgefin meistararitgerð). Háskóli Íslands, Reykjavík.

Sjöfn Kristjánsdóttir og Vanda Sigurgeirsdóttir. (2011). Einelti meðal barna frá sjónarhóli grunnskólakennara. Í Daníel Reynisson, Hjördís Árnadóttir, Sjöfn Kristjánsdóttir, Hrefna Friðriksdóttir, Halldór S. Guðmundsson og Vanda Sigurgeirsdóttir, Ábyrgð og aðgerðir. Niðurstöður pverfraeđilegrar rannsóknar á einelti meðal barna á Íslandi (bls 85-114). Reykjavík: Rannsóknarstofnun Ármanns Snævarr.

Smith, P. K. (2004). Bullying: Recent developments. Child and Adolescent Mental Health, 9(3), 98-103. doi:10.1111/j.14753588.2004.00089.x

Smith, P.K. og Shu, S. (2000). What good schools can do about bullying: Findings from a survey in English schools after a decade of research and action. Childhood:A Global Journal of Child Research, 7(2), 193-212. doi:10.1177/0907568200007002005

Smokowski, P. R. og Kopasz, K. H. (2005). Bullying in school: An overview of types, effects, family characteristics, and intervention strategies. Children and Schools, 27(2), 101-110. doi:10.1093/cs/27.2.101

Stassen-Berger, K. (2007). Update on bullying at school: Science forgotten? Developmental Review, 27(1), 90-126. doi:10.1016/j.dr.2006.08.002

Ttofi, M. M. og Farrington, D. P. (2011). Effectiveness of school-based programs to reduce bullying: A systematic and meta-analytic review. Journal of Experimental Criminology, 7(1), 27-56. doi:10.1007/s11292-010-9109-1

Ttofi, M. M., Farrington, D. P. og Lösel, F. (2012). School bullying as a predictor of violence later in life:A systematic review and meta-analysis of prospective longitudinal studies. Aggression and Violent Behavior, 17(5), 405-418. doi:10.1016/j. avb.2012.05.002

Vanda Sigurgeirsdóttir. (2003). Hvernig gengur kennurum að taka á einelti? Mat kennara á eigin farni og hugmyndir peirra að úrbótum (óútgefin meistararitgerð). Kennaraháskóli Íslands, Reykjavík.

Vanda Sigurgeirsdóttir. (2005). Kennarar og einelti. Í Ungir Íslendingar i ljósi vísindanna (bls. 91-96). Reykjavík: Umboðsmaður barna og Háskóli Íslands.

Vanda Sigurgeirsdóttir. (2016). Dolendur og gerendur [erindi á Menntakviku, ráđstefnu menntavísindasviðs Háskóla Íslands].

Vanda Sigurgeirsdóttir. (2017). Einelti, leiðir og lausnir. Í Alfa Aradóttir, Eygló Rúnarsdóttir og Hulda Valdimarsdóttir (ritstjórar), Frístundir og fagmennska. Rit um málefni frítímans (bls. 63-84). Reykjavík: Félag fagfólks í frítímapjónustu, Félag íprótta-, æskulýðs- og tómstundafulltrúa á Íslandi og Rannsóknarstofa í tómstundafræðum.

Vanda Sigurgeirsdóttir. (2018).Tíðni eineltis meðal nemenda í 6., 8. og 10. bekk á Íslandi [erindi á Menntakviku, ráđstefnu menntavísindasviðs Háskóla Íslands].

Vanda Sigurgeirsdóttir og Hrefna Sigurjónsdóttir. (2017). Handbók um einelti og vináttufarni. Forvarnir og viðbrögð. Reykjavík: Heimili og skóli. 
Vanda Sigurgeirsdóttir og Sif Einarsdóttir. (2004). Kennarar og einelti: Mat kennara á eigin pekkingu og færni við að taka á einelti meðal grunnskólanemenda. Uppeldi og menntun, 13(1), 79-96.

Vanderbilt, D. og Augustyn, M. (2010). The effect of bullying. Paediatrics and Child Health, 20(7), 315-320. doi:10.1016/j. paed.2010.03.008

Varjas, K., Henrich, C. C. og Meyers, J. (2009). Urban middle school students' perceptions of bullying, cyberbullying, and school safety. Journal of School Violence, 8(2), 159-176. doi:10.1080/ 15388220802074165

Yeager, D. S., Fong, C. J., Lee, H.Y. og Espelage, D. (2015). Declines in efficacy of anti-bullying programs among older adolescents:Theory and a three-level meta-analysis. Journal of Applied Developmental Psychology, 37, 36-51. doi:10.1016/j. appdev.2014.11.005

Yoon, J. S. og Kerber, K. (2003). Bullying: Elementary teachers' attitudes and intervention strategies. Research in Education, 69(1), 27-35. doi:10.7227/RIE.69.3

Yoon, J., Sulkowski, M. L. og Bauman, S. A. (2016). Teachers' responses to bullying incidents: Effects of teacher characteristics and contexts. Journal of School Violence, 15(1), 91-113. doi:10.1080/15388220.2014.963592

Vanda Sigurgeirsdóttir og Ársæll Már Arnarsson. (2018).

Viðhorf íslenskra grunnskólanema til eineltis og inngripa í eineltismál út frá reynslu peirra af einelti.

Netla - Veftímarit um uppeldi og menntun. Menntavísindasvið Háskóla Íslands.

Sótt af http://netla.hi.is/greinar/2018/ryn/14

DOI: https://doi.org/10.24270/netla.2018.14 